\title{
OBJECTIVE REGIMES REVISITED
}

\author{
Richard A. Barnes*
}

\section{INTRODUCTION}

International law is faced with increasing difficulties in regulating areas of common concern. This is particularly so in respect of the global environment and areas beyond respective national jurisdictions. Principally, the difficulties stem from the consensual nature of international law and the implication that States are bound only by that to which they have consented, and it is further compounded by the inability of States to reach agreement on matters of public interest. ${ }^{1}$ The severe consequences of this cannot be overstated, as Shelton has observed with regard to the problem of fishing:

'If time is taken to achieve unanimity through drafting, adopting, and enforcing a treaty or developing a norm of customary international law, the fish will long have disappeared'.2

The purpose of this article is to consider a possible alternative to the confines of the traditional law-making paradigm by making use of the untapped potential of objective regimes. ${ }^{3}$

The concept of the objective regime has been at the periphery of mainstream international legal doctrine for a long time without its potential having been fully explored. This is due mainly to the existence of the principle of pacta tertiis nec nocent nec prosunt: that treaties may only create rights and

\footnotetext{
* Richard A. Barnes is Sir Q. W. Lee and Dr. Peter Thompson Lecturer in Maritime Law, the University of Hull Law School.

1 A recent example of this is the difficulties in agreeing climate control measures at the Hague Conference Nov. 2000.

${ }^{2}$ D. Shelton, in J. Delbruck (ed.), New Trends in International Law Making: International 'Legislation' in the Public Interest (1997), 121.

${ }^{3}$ An objective regime may be defined as a situation of law created by the parties to an agreement, which purports to have directly applicable legal effects on third parties.
}

Asian Yearbook of International Law, Volume 9 (B.S. Chimni et al., eds.)

(C) 2004 Koninklijke Brill NV. Printed in The Netherlands, pp. 97-145. 
obligations binding on the parties to the treaty. ${ }^{4}$ This principle in turn flows from the notion of sovereignty. Given that article 34 of the Vienna Convention on the Law of Treaties, which embodies the pacta tertiis rule, provides that 'a treaty does not create either obligation or rights for a third State without its consent', it would appear that the concept of objective regimes is redundant. ${ }^{5}$ The present article suggests that this should not be assumed automatically, and that due recognition must be given to the changing nature of international law and the changing nature of sovereignty, with all the implications this has for the prescriptive process.

Part I focuses on the role of objective regimes in international law, exploring how objective regimes arise from deficiencies in the international prescriptive process, principally the absence of a supra-national institution capable of regulation in the international public interest. This will be followed, in Part II, by an examination of the evidence supporting objective regimes, and their existence as a legitimate exception to the pacta tertiis rule. It will be argued that a legitimate basis for an objective regime can be derived from the notion of general interests, as these have been recognised and consolidated by international practice and jurisprudence: general interests being those interests so essential and fundamental to international public policy as to provide States with a normative basis for the creation of objective regimes opposable to third parties. ${ }^{6}$ In the final part, the possible criteria for a normative category of objective regimes under customary international law will be outlined.

\section{THE ROLE OF OBJECTIVE REGIMES}

Objective regimes have received little attention in academic literature and as a result the concept occupies a rather ambiguous position within international law. The paucity of opinion reflects upon the controversial and uncertain status of the concept, and belies its potential importance. What opinion there is has focused on a number of potential bases, ranging from distinctions in categories of treaties to variants on the form of third party consent, without providing any one satisfactory and cohesive explanation. ${ }^{7}$

\footnotetext{
4 Hereinafter referred to as the pacta tertiis principle. The position is generally accepted. Thus SIR I. SINCLAIR notes that the 'maxim ... is supported both by general legal principle and by common sense', The Vienna Convention on the Law of Treaties, 2nd ed. (1984), 98; See also I. Brownlie, Principles of Public International Law, 4th ed. (1990), 622; Sir A. McNair, Law of Treaties (1961); R.F. Roxburgh, International Conventions and Third States (1917).

51155 UNTS 331; UKTS 58 (1980), Cmnd. 7964; (1969) 8 ILM 679.

6 The most sophisticated consideration of this is by E. Klein, Statusvertäge im Völkerrecht (1980).

7 For a proponent of the former opinion see McNair, op. cit., chap. XIV. Also C. ROUSSEAU, Principes Generaux du Droit International Public, vol. 2, 481, translated and cited by Fitzmaurice, [1960] YILC, vol. II, 92. For a proponent of the latter, see, for example, Fitzmaurice, who suggests
} 
More recently, some writers such as Klein, Chinkin and Subedi ${ }^{8}$ have acknowledged the potential of the concept and contributed towards the realisation of its utility by giving it a more defined content. A common element in most of the supporting doctrine is that the concept flows from structural weaknesses inherent in the international law-making process. More precisely, it derives from the absence of an objective form of law making capable of developing and prescribing the international public interest. It is insightfully put by McNair:

'When it is remembered that international society has at present no legislature, the treaty is the only instrument available for doing many of the things which an individual State would do by means of its legislature; and the making of rules of law is not the only function of a legislature. It is therefore not surprising that from time to time groups of States should have assumed the responsibility of leadership and used the instrument of a treaty to make certain territorial or other arrangements required, or which they consider to be required, in the interest of this or that particular part of the world. ${ }^{9}$

However, despite such limitations in the prescriptive process it still appears, at least according to prevailing doctrinal opinion, that consent is critical to the prescriptive process. ${ }^{10}$ Such strict orthodoxy should be modified and it should be accepted that consent is no longer as pivotal to the prescriptive process as it once was. ${ }^{11}$ The pacta tertiis rule is eroded,

there exists a general duty of States to respect and recognise the lawful international acts of other States, ibid. 96-100.

8 Klein, op. cit., n. 6 ; C. Chinkin, Third Parties in International Law (1993); S.P. Subedi, Land and Maritime Zones of Peace in International Law (1996).

9 McNair, op. cit., n. 3, at 259.

${ }^{10}$ I. Brownlie, op. cit., n. 4, 287; G. Schwarzenberger, International Law as Applied by International Courts and Tribunals: I, 3rd ed. (1957), $458 \mathrm{ff}$.

11 The consensual approach was famously stated in the Lotus case, when the PCIJ ruled that: 'International law governs relations between independent States. The rules of law binding upon States therefore emanate from their own free will as expressed in conventions or by usages generally accepted as expressing principles of law... Restrictions upon the independence of States cannot therefore be presumed.' (France v. Turkey), 1927 PCIJ, Ser. A, No. 10, at 18. There has been a definite move from this position, which can be seen in the debates on the persistent objector rule and has been called the 'acid test of custom's voluntarist nature'. P. Weil, 'Towards Relative Normativity?', (1983) 77 AJIL 413. However, the exact quality of the rule is subject to some debate. Contrast T.L. Stein, 'The Approach of the Different Drummer: The Principle of the Persistent Objector in International Law' (1985) Harvard International Law Journal 457 and J.I. Charney, 'The Persistent Objector and the Development of Customary International Law' (1985) 56 BYIL 1. The ICJ ruling, in the Legality of the Threat or Use of Nuclear Weapons case, ICJ Rep. 1996, at 226 indicates that States have no difficulty in maintaining their objection to a rule of custom when it conflicts with perceived vital interests. A. Steinfeld takes up this point in, 'Nuclear Objections: The Persistent Objector and the Legality of the Use of Nuclear Weapons', (1996) 62 Brooklyn Law Review 1635, at 1666-7. However, such a position must rely on the recognition of 
thus objective regimes can realise their potential to perform a surrogate legislative role in the absence of any formal institutionalised process. This proposition is not an isolated one, and can be associated with the growing corpus of law and opinion that supports a move away from a purely bilateral, voluntarist conception of the international legal system towards one that can accommodate a wider range of community and global interests. ${ }^{12}$

The critiques of bilateralism are a reflection of the dislocation of international law from international reality: that international law as a process is incapable of meeting the changing demands of international society. There are several strands to such critiques, which may be summarised as follows. Firstly, the interdependence of States has reached the point where it is impossible to define State interests in purely bilateral terms. Often the nature of interests at stake is independent of any single State's concern and requires a degree of co-operation that the traditional prescriptive process has difficulty in sustaining. ${ }^{13}$ This occurred in respect of the 1982 Law of the Sea Convention, with its complex interface of rights and obligations, interests and policies, which required a different approach to the traditional process of treaty negotiation. ${ }^{14}$ International environmental law is similarly affected, with effective regimes requiring a high degree of co-operation in order to succeed. ${ }^{15}$ Even modest arrangements between States will have some effect on third party States.

the relativity of State interests. Thus, the durability of the persistent objector rule was cast into doubt following the failure of the USA, the UK and Japan to withstand the move towards the 200-mile exclusive fishing zone. As the quality of interest at stake in any given situation affects the application of the persistent objector rule, this surely detracts from the seemingly critical element of consent. C. Tomuschat makes the point that the elucidation of the rule in practice and jurisprudence of the ICJ points away from the requirement of express or tacit consent to rules of custom. 'Obligations Arising for States Without or Against Their Will', (1997) 241 RdC 195 at 284-90.

${ }_{12}$ See generally Chinkin, op. cit., n. 8; Also B. Simma, 'From Bilateralism to Community Interest', (1994 - VI) 250 RdC 217. Philip Allott voices similar concerns, arguing that the bilateral forms of international law have impeded the articulation of true social objectives, 'Mare Nostrum: A New Law of the Sea' (1992) 86 AJIL 764. Eli Lauterpacht considers this in respect to the submission of States to judicial redress, and the process of erosion that the principle of consent is undergoing, in Aspects of the Administration of International Justice (1991), 23 - 57. Cf. P. Weil, ibid.

${ }^{13}$ Despite consent's other virtues, it is axiomatic that specific agreement on matters of global concern is difficult to achieve. As the number of parties and issues under discussion are increased, so gaining consent becomes more difficult. See Mancur Olson, The Logic of Collective Action: Public Goods and Theory of Groups (1965), 53-65. Another related concern is 'cost of consent'. The transaction cost of reaching agreement rises in line with the expanded scope of the subject matter and participants, acting as a further disincentive to agreement. See J.M. Buchanan and G. Tulloch, The Calculus of Consent (1962), 112.

${ }^{14}$ B. Buzan, 'Negotiating by consensus: developments in technique at the United Nations Conference on the Law of the Sea', (1981) 75 AJIL 324; H. Caminos and M. Molitar, 'Progressive development of international law and the package deal', (1985) 79 BYIL 871.

15 See G. Palmer, 'New ways to make international environmental law', (1992) 86 AJIL 259. 
Secondly, international regulation has expanded into areas previously outside the traditional scope of international law, such as human rights and environmental law. This expansion poses a number of questions for the traditional bilateral system. It is axiomatic that certain concerns of the environment transcend those of individual States, for example, the global climate, the atmosphere, or even genetic diversity and integrity. Environmental law must also concern itself with the allocation and protection of resources beyond national jurisdiction. ${ }^{16}$ The bilateral system is not always the best means of dealing with environmental problems as it cannot easily or directly take account of non-State interests or interests transcending individual States. The concerns of international environmental law often exist in opposition to the economic and political interests of States and have no independent voice. A particularly important development is the notion that we are trustees for the environment. As Judge Weeramantry notes:

'Natural resources are not individually, but collectively, owned, and a principle of their use is that they should be used for the maximum service of people. ${ }^{17}$

Unless the law-creating process can take account of this, then such concerns will remain at the periphery of international law or as unresolved issues.

Thirdly, there is a growing need to accommodate the interests of a wider range of subjects into the prescriptive process than those permitted by the bilateral modal of international law. ${ }^{18}$ The rights and duties of sub-State entities, international organisations, individuals and trans-national corporations need to be taken into account. Fourthly, the fora for the creation of international law are typically multiparty in their nature, and this in turn exacerbates the strains on the system. The massive time and effort that were necessary to facilitate and create the LOSC is a prominent example. Similarly, it is now not uncommon for third-party States to intervene into judicial proceedings, so straining the judicial process. ${ }^{19}$ This tendency towards

${ }^{16}$ See for example Part XI of the United Nations Convention on the Law of the Sea 1982, (1982) 21 ILM 1261, hereinafter LOSC. Also the Antarctic Treaty 1959402 UNTS 71, UKTS 97 (1961), Cmnd. 1535, (1960) 54 AJIL 477, and the Outer Space Treaty, UKTS 10 (1968) Cmnd, 3519, 610 UNTS 205.

17 Judge Weeramantry in the Gabčikovo-Nagymaros case, ICJ Rep. 1997, 1

18 As A.S. Burley notes, international law "has to take into account increasing evidence of the importance and impact of so many factors excluded from the reigning model: individuals, corporations, non-governmental organisations of every stripe, political and economic ideology, ideas, interests, identities and interdependence.', 'International Law and International Relations Theory: A Dual Agenda', (1993) 87 AJIL 202, at 227.

19 The intervention of Malta in the Case Concerning the Continental Shelf (Tunisia/Libya), Application to Intervene, ICJ Rep. 1981, 3; Italy's intervention in the Case Concerning the Continental Shelf (Libya/Malta), Application to Intervene, ICJ Rep. 1984, 3; Nicaragua's intervention in the Land, Maritime and Frontier Boundary Dispute (El Salvador/Honduras), Application by Nicaragua for Permission to Intervene, ICJ Rep. 1990, 92; Case Concerning the Land and Maritime Boundary 
multiparty law creation inevitably incorporates a wider range of interests into legal instruments, and can only compound the interrelationship of State interests. A final strand in this trend can be discerned in the changing objectives of international law. Classical international law has been principally concerned with allocating decision-making competence between States, and so the goal of international law is generally State-orientated. Allot argues that during the sixteenth and seventeenth centuries there occurred a disaggregation of interests, whereby the State, then meant to represent the collective interests of a particular society, became the primary objective of international law. ${ }^{20}$ Only recently is this approach being challenged, with the emergence of human rights, and the projection of individual and human objectives as the true goals of international law. Growing recognition that human goals, and not State goals, should be the principal objective of international law is challenging the notion of sovereignty and thus voluntarist modes of law making.

Cumulatively, these changes are working to undermine the traditional bilateral model of international law, forcing us to reconsider our preconceived ideas of the law creation process. As Chinkin remarks in conclusion to her comprehensive study on third parties in international law:

'[T]he problems these present cannot be satisfactorily determined either by formalistic application of the traditional rules which were formulated in a bilateral context, by rejection of new modalities for change in international law, or by a continued emphasis on bilateralism in proceedings before international adjudicative arenas'. ${ }^{21}$

If the traditional model is unrepresentative of international reality then we need to redefine its particular modes of operation to take account of such changes. The pacta tertiis rule is derived from a strong bilateral model based on an anachronistic conception of sovereignty. If sovereignty is rejected or redefined, it follows that the pacta tertiis rule must also be rejected or redefined. The rejection of bilateralism is not a recent phenomenon, but is part of the on-going process of the reconceptualising of international law, and in particular the notion of sovereignty and its close lieutenant, consent. Several eminent publicists have fuelled this discourse. Waldock, for example, adopted a limited view of sovereignty:

'It expresses the fact that the international legal order operates on the general basis of the co-ordinate and equal authority of the States whose relations it primarily regulates. The doctrine becomes pernicious only when it is distorted so as to imply that sovereignty is a quality inherent in all States which makes it impossible for them

Between Cameroon and Nigeria (Cameroon v. Nigeria), Application by Equatorial Guinea for Permission to Intervene, ICJ Rep. 1999, 3 (Order 21 October 1999).

20 Allott, op. cit., n. 12, at 775.

21 Chinkin, op. cit., n. 8, at 356. 
to be fully subordinated either to the rule of law or to control by any international authority'. 22

Indeed, a restrictive understanding of sovereignty is now generally accepted as consistent with State practice and the decisions of the International Court of Justice. ${ }^{23}$ As Judge Anzilotti stated:

'The sovereignty of the State consists of its competence as defined and limited by international law and is not a discretionary power which overrides the law'. ${ }^{24}$

Similarly, Lauterpacht notes:

'There is no room in a developing international society for a rigid application of the principle according to which the rights and duties of a State can never be determined by a will other than its own'. ${ }^{25}$

Any allusions to extensive notions of sovereignty can only relate to the internal affairs of States within the boundaries determined by international law. ${ }^{26}$ Sovereignty is understood to mean the relative position of States vis $\grave{a}$ vis each other subject to the system of international law. Accordingly, Wildhaber reasons that 'it (sovereignty) certainly does not qualify as ius cogens ${ }^{27}$ A principle of ius cogens is a rule of substance, and is not relative to other rules of law; sovereignty is not non-derogable. In any case, the creation of a particular objective regime should not be regarded as the subordinating of one group of States to the will of another group of States, but rather the subordinating of all States concerned to a particular and legitimate rule of law.

\section{EXCEPTIONS TO THE PACTA TERTIIS RULE}

Treaties are the favoured vehicles of States for codifying and developing international law because they are derived from a deliberative process and are capable of imposing precise and binding rules. More importantly, they

${ }^{22}$ H. Waldock, 'General Course on Public International Law', (1962-ii) 106 RdC 1, at 157. See also Lauterpacht, The Development of International Law by the International Court (1958), 297-400; G. Fitzmaurice, 'The Law and Procedure of the International Court of Justice, 1951-54: General Principles and Sources of Law', (1931) 30 BYIL 1, at 8-18.

${ }^{23}$ See the Corfu Channel case (Merits), ICJ Rep. 1949, 4 at 29-30. Also the Reservations to the Convention on Genocide, Advisory Opinion, ICJ Rep. 1951, 15 at 24.

${ }^{24}$ Austro-German Customs Union case, 1931 PCIJ Ser. A/B, No. 41, 3.

25 Lauterpacht, op. cit., n. 22, at 180-181.

${ }^{26}$ See generally the Island of Palmas case (Netherlands v. U.S.) (1928) 2 RIAA 829.

${ }^{27}$ L. Wildhaber, 'Sovereignty and International Law', in R. St. MacDonald and D. M. Johnston (ed.) The Structure and Process of International Law (1986). 
are underpinned by the fundamental principles of State sovereignty and equality as reflected in the pacta tertiis rule and framed by article 34 of the Vienna Convention. ${ }^{28}$ Although this general rule is widely regarded as fundamental to treaty law, there is a degree of uncertainty as to the extent to which the rule has been modified to take account of the changing demands of international political reality, and whether exceptions to it exist. Even within the Vienna Convention the need for flexibility is acknowledged and accounted for, with articles 35 and 36 providing that rights and obligations may be created for third parties where it is so intended and where the third parties consent to the rights and obligations. ${ }^{29}$ Furthermore, article 38 provides that 'nothing in Articles 34 to 37 precludes a rule set forth in a treaty from becoming binding upon a third State as a customary rule of international law, recognised as such'. The inclusion of these provisions demonstrates that a purely contractual scope for treaties would be unduly restrictive for States and their desire to create norms of general application. ${ }^{30}$ Although these qualifications are more apparent than real, in that they merely amount to a restatement of the need for consent, they imply that an absolutist approach to the pacta tertiis rule and third parties is unacceptable.

To confine ourselves to the narrow approach of the Vienna Convention to the pacta tertiis rule would be misleading, especially as the convention is not intended as a definitive code. ${ }^{31}$ During the draft stages of the convention a wider range of issues was discussed; these failed to become part of the final draft. Of particular importance are the reports of Special Rapporteurs Fitzmaurice and Waldock, both of whom supported the inclusion of articles providing for objective regimes. ${ }^{32}$ Such provisions were excluded from the

\footnotetext{
${ }^{28}$ The pacta tertiis rule is widely regarded as fundamental. See article 18 of the Harvard Research Draft Convention on Treaties (1935) 29 AJIL Supplement; B. Cheng, 'Custom: The Future of General State Practice In a Divided World' in R. St. MacDonald and D. M. Johnson (ed.), op. cit.; Roxburgh, op. cit., n. 4, at 29; Sinclair, op. cit., n. 4 at 98; Brownlie, op. cit., n. 4, at 622; McNair, op. cit., n. 4 , at 309 .

${ }^{29}$ Article 35 states: 'An obligation arises for a third State from the provision of a treaty if the parties to the treaty intend the provision to be the means of establishing the obligation and the third State expressly accepts that obligation in writing'. Article 36 states: 'A right arises for a third State from a provision of a treaty if the parties to the treaty intend the provision to accord that right either to the third State, or to a group of States to which it belongs, or to all States, and the third State assents thereto. Its assent shall be presumed so long as the contrary is not indicated, unless the treaty otherwise provides.'

${ }^{30}$ Prosper Weil has pointed out that the distinction between treaty norms and customary norms (and indeed between hard and soft law) is becoming increasingly blurred. Op. cit. n. 12 at 438-440.

${ }^{31}$ The preamble to the convention notes that 'the rules of customary international law will continue to govern questions not regulated by the provisions of this convention'. Thus, customary rules may emerge to supplement those enshrined in the Vienna Convention.

${ }^{32}$ Waldock's report to the ILC contained a draft article on treaties providing for objective regimes, and a comprehensive commentary. Article 63(1) states: 'A treaty establishes an objective regime when it appears from its terms and from the circumstances of its conclusion that the intention of the parties is to create in the general interest general obligations and rights relating to a particular
} 
conventions only so as to encourage States to participate in the convention. The majority opinion was that the controversial nature of the provisions would impair the potential success of the treaty rather than having no basis in law. ${ }^{33}$ Indeed, Fitzmaurice felt able to conclude that such exceptions 'constitute in the aggregate a considerable gloss on the pacta tertiis rule. ${ }^{34}$

In any case it is widely accepted that the provisions of the Vienna Convention do not cover every eventuality. ${ }^{35}$ Important developments have taken place beyond the Vienna Convention, and there is a substantial body of practice, jurisprudence and academic opinion that amount to more than just a 'gloss' on the pacta tertiis rule. ${ }^{36}$ These provide evidence of a range of exceptions to the pacta tertiis rule and of the existence of objective regimes. State practice in support of objective regimes is evident in a number of areas. These include international settlements, ${ }^{37}$ boundary agreements, ${ }^{38}$ and internationalised territories. ${ }^{39}$ The binding erga omnes character of such arrangements is generally accepted, and, as they have been reviewed elsewhere, I wish to concentrate on how the category of objective regimes has

region, State, territory, locality, river, waterway, or to a particular area of the sea, sea-bed, or airspace; provided that the parties include among their number any State having territorial competence with reference to the subject matter of the treaty, or that any such State has consented to the provision in question.', [1964] YILC, vol. II, 26ff.

33 See generally, the 738th, 739th, and 740th meetings of the ILC, [1964] YILC, vol. I, 96ff.

34 [1960] YILC, vol. II, 73.

35 The present discussion raises an interesting point as regards the application of the Vienna Convention. Article 1 states that 'the present Convention applies to treaties between States'. Under article 305 of the LOSC and article 2 of the 1995 Agreement non-State entities may participate in the agreements. Strictly speaking, this precludes the application of the rigid treaty rules incorporated in the Vienna Convention from the those agreements. However, it must be noted that this does not preclude the application of the underlying rules of international law. It remains to be seen whether these exactly mirror those of the Vienna Convention.

36 The recent works of Chinkin and Subedi are illustrative of this decline in practice of the rigid application of the principle, op. cit., n. 8. See also Subedi, 'The Doctrine of Objective Regimes in International Law and the Competence of the United Nations to Impose Territorial or Peace Settlements on States', (1994) 37 German Yearbook of International Law 162; P. Birnie, infra $\mathrm{n}$. 50, at 243-249. Cf. C.L. Rozakis, 'Treaties and Third States: a Study in the Reinforcement of the Consensual Standards in International Law', (1975) 37 ZaöRV 1.

37 The Treaty of Utrecht 1713 in respect of certain territories including Gibraltar, the Congress of Vienna, establishing the permanent neutrality of Switzerland and the Treaty of Versailles 1919, in respect of Germany. The demilitarisation of certain Iraqi territory under Security Council Resolution 687 (1991) may be regarded as a recent example of an international settlement. See also the Treaty on the German Re-unification, (1990) 29 ILM 1187.

38 Articles 11 and 12 of the Vienna Convention on Succession of States in Respect of Treaties reaffirms this by maintaining the legitimacy of boundary agreements vis à vis a succession of States. See generally [1974] YILC, vol. II, $196 \mathrm{ff}$.

39 See generally, the mandate system as established under the League of Nations. The objective character of such regimes was reaffirmed in the International Status of South West Africa Advisory Opinion, ICJ Rep. 1950, 132. In particular, McNair's separate opinion, at 153-155. 
expanded. ${ }^{40}$ It is notable that certain regimes have proved viable because they have been crucial to the maintenance of international public order or peace and security; they are perceived as being in the general interest of the international community. It is reasonable to assume that as the range of general interests expands from encompassing simply peace and security, to including the protection of the environment and conservation and management of resources, so too does the potential for the creation of objective regimes. The following review of practice, jurisprudence, and doctrine considers extraterritorial regimes, environmental protection zones, and demilitarised zones, showing how the potential of the concept has developed.

\subsection{Extra-territorial regimes}

International law recognises the competence of States to regulate areas beyond national jurisdiction. The principal areas that have been subject to regulatory regimes are Antarctica, Outer Space, the Deep-sea Bed, the High Seas, and 'Zones of Peace'. ${ }^{41}$

\subsubsection{The Antarctic ${ }^{42}$}

The Antarctic Treaty of 1959 was concluded by the 'Antarctic Club' group of States and is regarded as establishing a regime for the peaceful use of Antarctica. ${ }^{43}$ As the preamble states:

'It is in the interest of all mankind that Antarctica shall continue for ever to be used exclusively for peaceful purposes and shall not become the scene or object of international discord.'

It then goes on to align the treaty regime with the purposes and principles embodied in the United Nations Charter. Individual provisions develop this purpose and establish a particular status for Antarctica, which, implicitly, has

\footnotetext{
40 Fitzmaurice, op. cit., n. 77; McNair, op. cit., n. 4; Greig, infra n. 172172; Crawford, infra n. 171; See also The SS Wimbledon case, 1930 PCIJ Ser. A, No. 1, 15 at 28.

${ }^{41}$ Zones of Peace shall be considered under the heading of "3.3. Neutrality and demilitarisation".

${ }^{42}$ Antarctica is regulated by a number of treaties, collectively known as the Antarctic Treaty System, hereinafter referred to as the ATS.

43 The 'Antarctic Club' is comprised of the original claimants to territory: Argentina, Australia, Chile, France, New Zealand, Norway and the United Kingdom, along with Belgium, Japan, South Africa, the USSR and the United States. The parties to the treaty regime have since expanded beyond this limited group. For a more rounded discussion see J. Crawford and D. R. Rothwell, 'Legal Issues Confronting Australia's Antarctica', (1992) 13 Australian Yearbook of International Law 62; B. Simma, 'The Antarctic Treaty as a Treaty Providing for an Objective Regime', (1986) 19 Cornell International Law Journal 189
} 
objective effects. Article I prohibits military activities in the region, ${ }^{44}$ and article $\mathrm{V}$ prohibits certain nuclear activities in region. ${ }^{45}$ Article IV(2) prohibits claims to sovereignty over Antarctica. ${ }^{46}$ Article $\mathrm{X}$, which requires the Contracting Parties to 'exert appropriate efforts, consistent with the Charter of the United Nations, to the end that no one engages in any activity in Antarctica contrary to the principles or purposes of the present treaty', clearly evidences an intention for the regime to have objective effects. ${ }^{47}$ The 1959 Treaty has been supplemented by other instruments, which may also provide rights or obligations for third States. The Convention on the Conservation of Antarctic Marine Living Resources provides numerous benefits, such as the right to participate in harvesting and research. ${ }^{48}$ This is bolstered by a duty to facilitate research and studies, and from the data to be provided. Third parties also benefit from the conservation of resources and the measures established to this end. The Convention on the Regulation of Antarctic Mineral Resource Activities provided for similar benefits to accrue. ${ }^{49}$ Although there may be problems in enforcing obligations against third States these are not insurmountable, and for the most part this would depend on how far the contracting States would be prepared to go in enforcing the provisions of the treaty regime.

The opinion of writers on the nature of the ATS is quite divided. ${ }^{50} \mathrm{How}-$

\footnotetext{
${ }^{44}$ Article I: 'Antarctica shall be used for peaceful purposes only. There shall be prohibited, inter alia, any measures of a military nature, such as the establishment of military bases and fortifications, the carrying out of military manoeuvres, as well as the testing of any type of weapons.'

45 Article V(1): 'Any nuclear explosions in Antarctica and the disposal there of radioactive waste material shall be prohibited.'

${ }^{46}$ Article IV(2): 'No acts or activities taking place while the present treaty is in force shall constitute a basis for asserting, supporting or denying a claim to territorial sovereignty in Antarctica or create any rights of sovereignty in Antarctica. No new claim, or enlargement of an existing claim, to territorial sovereignty shall be asserted while the present treaty is in force.'

47 See also article XXII(1) of CCAMLR, (1980) 19 ILM 841.

48 Ibid.

49 (1988) 27 ILM 868. This regime has since been superseded by the Madrid Protocol on Environmental Protection, which designates Antarctic as a 'natural reserve, devoted to peace and science' and places an indefinite ban on any mineral activities other than for scientific purposes. (1991) 30 ILM 1455 .

${ }^{50}$ The divided opinions on whether the 1959 Antarctic Treaty establishes an objective regime demonstrate this. See generally Sir Arthur Watts, International Law and the Antarctic Treaty 1992. In favour of such a regime are: R. D. Hayton, 'The Antarctic Settlement of 1959', (1960) 54 AJIL 349; P. Birnie, 'The Antarctic Regime and Third States' in R. Wolfrüm, (ed.) Antarctic Challenge II (1986). However, she notes that there are problems with this in relation to the expanding nature of the Antarctic regime. Boczek notes that a majority of Soviet writers support the conclusion that the 1959 Treaty establishes an objective regime, 'The Soviet Union and the Antarctic Regime', (1984) 78 AJIL 834, at 856. Those writers opposed to such a notion include: J.N. Barnes, ' The Emerging Antarctic Living Resources Convention' [1979] ASIL proc. 272; I. Brownlie, 'Legal Status of Natural Resources', (1979-I) 162 RdC 245; J. Hanessian, 'The Antarctic Treaty 1959', (1960) 9 ICLQ 436. M. W. Mouton suggests that the treaty may be considered objective law if it is
} 
ever, the inadequate depth of reasoning in most instances makes it difficult to assess the value of such assertions. Opinions swing heavily within the interpretation of the key provisions, which are by their nature ambiguous and inconclusive. Some illumination can be drawn from precedent in other areas. Thus the Permanent Court in the Wimbledon case ${ }^{51}$ considered that provisions of the Versailles Treaty, concerning the Kiel Canal, evidenced an intention to create an international regime. There is a clear parallel in the case of Antarctica. Elsewhere, negative provisions, such as demilitarisation, have also been upheld as objective, suggesting that the corresponding provisions of the Antarctic Treaty could be regarded in the same light. ${ }^{52}$ The clear intention of the parties to establish objective rights and duties, combined with the general interest of all States in the objectives set out in the treaty, led Waldock to consider the Antarctic Treaty as an objective regime. ${ }^{53}$ More recently, Birnie followed this approach, but noted that the whole system is unlikely to represent an objective regime as a consequence of third States' dissatisfaction with the special role of the original contracting States. ${ }^{54}$ Thus, political objections, rather than legal considerations, critically affect the status of the Antarctic as an objective regime. Political concessions have not been forthcoming so as to enhance the objective status of the regime, and were it not for these political obstacles then the practice of States might be more conclusive on the matter of whether or not the regime is truly objective.

It may be argued that the ATS has been overtaken by customary rules to the same effect and some points should be made in response. Firstly, the existence of customary rules does not render the objective character of the ATS moot, for there are numerous instances of parallel rules of treaty and custom co-existing, each with different implications. ${ }^{55}$ It is also debatable whether all of the provisions of the ATS satisfy the criterion for a customary rule as set out in the North Sea Continental Shelf cases. ${ }^{56}$ Secondly, certain provisions of the Antarctic Treaty are of an institutional nature and it is doubtful whether these could be sustained under a rule of customary law. ${ }^{57}$ As such there is still a considerable value in conceiving of the ATS as an objective regime.

recognised as representing general international law, and thus enforceable erga omnes, 'The International Regime of the Polar Regions', (1962-III) 107 RdC 174, 258.

51 Supra n. 40 , at 28.

52 The Aaland Islands case, League of Nation Official Journal, Special Supplement No. 3, (October 1920), 16.

53 Op. cit., n. 32, at 30.

54 Op. cit., n. 50, at 260.

55 See generally, the Nicaragua case (Merits) (Nicaragua v United States), ICJ Rep. 1986, 14, para $175 \mathrm{ff}$.

56 ICJ Rep. 1969, 3.

57 For example, article IX provides for periodic meetings of the consultative parties, which have led to numerous recommendations purporting to regulate a variety of activities from scientific activity to the exploitation of living and non-living resources. 


\subsubsection{Outer space}

The regime created by the Outer Space Treaty $1967^{58}$ is another candidate for an objective regime, although the discussion is necessarily constrained by the practical and technical limits presently inherent in the use of outer space. As in the Antarctic Treaty, the preamble refers to the 'common interest' and 'the benefit of all peoples', and this is backed up by two provisions purporting to establish rules of general application. Article 1 states that the 'exploration and use of outer space ... shall be carried out for the benefit and in the interests of all countries ... and shall be the province of all mankind'. It continues to provide for a freedom of exploration and access, and of scientific information. Article 2 then provides that outer space, including celestial bodies, shall be free from appropriation by claims of sovereignty. Although the remaining provisions are addressed towards States Parties only, it is evident that the treaty purports to establish limited rights and obligations of an objective or general nature, and the question remains to what extent these provisions have any impact on third parties.

The permissive nature of article 1 means that it is politically unobjectionable, in much the same way as is the freedom of the seas. This freedom is reinforced by article 2 , which takes the regulation of outer space beyond the competence of any single state, and renders its regulation the concern of all. The acceptability of these rules is reflected in the wide participation of over 60 States in the treaty, and arguably, its provisions are now enshrined in customary law. ${ }^{59}$ This, combined with the fact that, apart from the use of space for satellites, space is subject to very little actual practice, means that the question of the opposability of the regime is unlikely to be tested. However, it is arguable that given the lack of practice in this area the position of third States is likely to be derived to some extent from the rights and obligations set out in that treaty. Thus, the objective nature of the Outer Space Treaty is likely to remain a matter of speculation for the foreseeable future, unless space for satellites becomes critical, or energy and mineral resource exploitation become a realistic possibility.

However, one can derive some illumination from outer space regime. Despite the treaty's having a predominantly contractualnature, its evolution reflects the very same process we are considering in respect of objective regimes, namely, the existence of principles and rules articulating a general interest of international society and its actualisation in a treaty with objective

\footnotetext{
58 The Treaty on the Principles Governing the Activities of States in the Exploration and Use of Outer Space, including the Moon and Other Celestial Bodies, UKTS 10 (1968) Cmnd. 3519; 610 UNTS 205.

${ }^{59}$ It should be pointed out that through the customary process certain technically advanced developed States would have a distinct influence on the development of customary norms. This raises in respect of customary rules issues of legitimacy and authority that are not so acute as when the law is formulated through the treaty-making process.
} 
potential. Thus, the general interests in the regime of outer space, as articulated in General Assembly Resolutions 1962(XVII) and 1721(XVI), evolved into a treaty regime, the Outer Space Treaty, with objective potential. A leading author on space law has described these instruments as "forming part of an international ordre public, to which States should strive to make their policies conform. ${ }^{60}$ The Outer Space Treaty realises these interests in a more substantial form, rendering them opposable by other States. Undoubtedly, parts of the regime under the Outer Space Treaty are framed in terms of general obligations and so have an impact on the respective positions of non-parties.

Presently, the regime for Outer Space is relatively uncontroversial and thus has garnered a good degree of support and acquiescence. Yet once the potential for resource exploitation becomes feasible then this situation is likely to change and States will have to confront those concerns that are currently being addressed in respect of the Deep Sea-bed or other shared resource regimes. Once this occurs then treaty law will have to define more precisely a State's rights and obligations, and thus merit a reconsideration of the regime as a whole, along with its implications for third parties.

\subsubsection{The deep sea-bed ${ }^{61}$}

By definition the international sea-bed falls beyond national jurisdiction and as such the regulation of the area is a matter for international co-operation. ${ }^{62}$ As a territorial regime beyond the limits of national jurisdiction, the deep sea-bed merits consideration as an objective regime because co-ordinated regulation will inevitably have an impact on third States. Although its status as an objective regime is generally rejected, it is useful to reconsider such arguments as they illustrate the interplay of legal issues relevant to the present discussion. ${ }^{63}$ In particular it illustrates the importance of general interests and competence to the doctrine of objective regimes.

\footnotetext{
60 J. Fawcett, International Law and the Uses of Outer Space (1968), 16.

${ }^{61} 1970$ Common Heritage Declaration on the Deep Sea-bed, UN GA Res. 2749 (XXV). The 1971 Treaty on the Demilitarisation of the Seabed, UKTS 13 (1973), Cmnd. 5266; 955 UNTS 115. Part XI of LOSC; 1994 Agreement Relating to the Implementation of Part XI of LOSC, (1994) 33 ILM 1309.

${ }^{62}$ Article 1 of the LOSC defines it as the "seabed and ocean floor and subsoil thereof beyond national jurisdiction'. Article 137(2) provides that 'All rights and resources of the Area are vested in mankind as a whole ...'.

${ }^{63}$ See S. Vasciannie, 'Part XI of the Law of the Sea Convention and Third States: Some General Observations', (1989) 48 Cambridge Law Review 85; D. Arrow, 'Seabeds, Sovereignty and Objective Regimes', (1984) 7 Fordham Journal of International Law 169; E. Brown, Seabed Energy and Mineral Resources and the Law of the Sea. Vol. ii. The Area Beyond the Limits of National Jurisdiction (1986), at II.3 14.
} 
The key question is whether or not Part XI of the LOSC creates obligations for States and other entities not party to it. During the plenary meetings of UNCLOS Mr Perisič of Yugoslavia raised exactly this point:

\begin{abstract}
'The question is to what extent the principle pacta tertiis nec nocent nec prosunt could be applied in the matter of the common heritage of mankind. The convention would merely define more precisely the method of exploitation of the area and resources which according to the 1970 Declaration belonged to all States. Account must also be taken of the possibility that States not parties to the convention might also participate in the exploitation of the resources of the seabed beyond the limits of national jurisdiction. The participation of third States was provided for in several international treaties or conventions. ${ }^{64}$
\end{abstract}

The suggestion is that the regime does have an impact on third parties, and third parties should at the very least respect conventional obligations in that these are merely a manifestation, in a more specific form, of a general rule relating to the common heritage of mankind.

Arguably, the LOSC intends to create objective rights and a literal interpretation of Part XI appears to support such a position, as it clearly distinguishes between rights and obligations for States Parties, and the rights and obligations for States generally. More particularly, article 136 of the LOSC defines the juridical status of the Area and its resources as the common heritage of mankind', with article 137 stating:

\begin{abstract}
'No State shall claim or exercise sovereignty or sovereign rights over any part of the Area or its resources, nor shall any State or natural or juridical person appropriate any part thereof. No such claim or exercise of sovereignty or sovereign rights shall be recognised.'
\end{abstract}

Article 140 requires that activities in the area must be carried out for the benefit of all States.

Articles 139, 143, 144(2) and 156, which specifically outline obligations for States Parties, are in stark contrast and this suggests differentiated levels of obligations. This interpretation of Part XI has its opponents, with some authors strongly disputing that it has objective effects. From the travaux préparatoires, Lee highlights statements by State representatives, which suggest that no such intention to create an objective regime existed. ${ }^{65}$ Yet the LOSC is commonly referred to as a constitution for the oceans, and the practical distinction between such a legal order and an objective regime appears slight. Arrow argues that certain provisions of the LOSC are conclusive evidence of the lack of intention to create an objective regime. He cites articles 306 and 317, which open up the treaty to ratification and de-

${ }^{64}$ Plenary Meeting, 5 May 1978, UNCLOS III Off. Rec., vol. IX, 31.

${ }^{65}$ L.T. Lee, 'The Law of the Sea Convention and Third States' (1983) 77 AJIL 541, at 548. 
nunciation, and article 311, which provides that the convention 'shall prevail, as between States Parties, over the Geneva Convention' as evidence that the LOSC applies only to the parties. ${ }^{66}$ However, these are simply standard clauses that are inserted into most treaties, and in any should be understood merely as defining the relationship between LOSC and the 1958 Convention. It is equally possible to cite other provisions that can be held up to support the view that differentiated obligations exist, such as article 2(1), which expressly defines and so distinguishes States Parties from States. The preamble stresses the aim to create a global order for the oceans in the interests of the international community as a whole. It seems trite to note that the opportunity for non-parties to exploit freely the deep sea-bed contrary to the provisions of Part XI, or beyond the institutional provisions of that regime, is inimical to the whole purpose of creating a global regime. Despite this critical concern it appears that an unequivocal intention to create objective obligations cannot be established and this weakens the case for the Area as an objective regime. Although it may be certain that the regime will have an impact on non-parties, and that this was certainly in the mind of the drafts(wo)men, it is doubtful that this is sufficient to rebut the presumption that a treaty has effect res inter alios acta.

Even if sufficient intention can be inferred from the terms of the LOSC, and from the statements of the parties, we must further consider another key prerequisite for an objective regime: the existence of general interest in the regime for the deep sea-bed. To what extent does Part XI of the LOSC legislate in the general interests of the international community? On first reading, such an interest seems to be manifest in the concept of the common heritage of mankind. At the conference some parties argued that this notion was fundamental and that it should be given the status of ius cogens. ${ }^{67}$ However, given the then ambiguous status of the Common Heritage of Mankind, this proved to be overly ambitious, and the outcome of the discussion on the nature of the concept was article 311(6), which provides:

'States Parties agree that there shall be no amendments to the basic principle relating to the common heritage of mankind set forth in article 136 and that they shall not be a party to any agreement in derogation thereof.'

On the one hand this provision obliges parties to the convention merely to respect the common heritage principle, suggesting that it is something less than fundamental, but on the other categorises it as a 'basic principle'. In any case, Part XI was riven by disagreement, which necessitated further treaty negotiations, suggesting that even if the parties had realised that a general interest in the exploitation and regulation of the Deep Sea-bed existed, no

${ }^{66}$ Op. cit., n. 63, at 227.

${ }^{67}$ See the Informal Proposal by Chile to include a provision to this effect, Eighth Session, Part II, FC/14, 20 August 1979. 
one could agree on its substantive content. ${ }^{68}$ This of course poses a serious impediment to the suggestion that the Area is an objective regime. The difficulty in identifying a general interest is compounded by the character of the LOSC as a package deal. This involved a trade-off of interests, a bartering process for the inclusion of certain substantive provisions, the inclusion of which does not necessarily rely on their normative content, but instead on their political acceptability. This element of political expediency, which is systemic in the LOSC, further undermines the argument in favour of an objective regime as it suggests that many provisions will not reflect true legal consensus on matters of general interest. The absence of anything more than an abstract general interest in the Area serves to weaken its candidature for consideration as an objective regime. Even if such an interest could be ascertained, the treaty must then be able to articulate rights and obligations that correspond to it. A failure to achieve this is critical in respect of the Deep Sea-bed.

A further objection is raised by Vasciannie who argues that, even if the doctrine of objective regimes could withstand scrutiny, it would be inapplicable to the Area by virtue of the lack of treaty making competence over the territory by any of the parties. ${ }^{69}$ He reasons that since the Deep Sea-bed is

' $[P]$ er definitionem, not subject to the special competence of any State, it cannot become the subject of an objective regime in the classical sense'. ${ }^{70}$

He adopts the position of Waldock, Special Rapporteur to the ILC during the drafting of the Vienna Convention on the Law of Treaties, in arguing that one or more of the parties must have in respect of the territory a particular treaty-making competence which other States do not have. ${ }^{71}$ However, such a position effectively rules out the existence of objective regimes in areas beyond national jurisdiction, and as a consequence seriously limits the practical scope for objective regimes.

The first point to make in response to this view is that the juridical nature of the Deep Sea-bed does not absolutely prohibit States' legislative competence. The Area is generally categorised as res communis, which permits its use by any State while prohibiting claims to exclusive title. States may assert prescriptive competence over the Area to the extent that it does not amount to a claim of exclusive title, or to a lesser extent, an unjust inter-

\footnotetext{
${ }^{68}$ Common Heritage of Mankind has three facets: demilitarisation of the sea-bed, the prohibition of claims to sovereignty over the sea-bed, and the establishment of an equitable regime for exploration and exploitation. Of these the last two are intricately related and give rise to a highly developed concept of trusteeship, yet they are also the most controversial aspects of the notion.

69 Op. cit., n. 63, 90.

70 Ibid.

71 Waldock, [1964] YILC, vol. ii, 26 at 31.
} 
ference with the rights of other States. Secondly, as was pointed out earlier, a restrictive view of competence, limited to territorial competence, relies upon historically prevalent notions of State sovereignty and pays little heed to contemporary conceptions of States' authority or interests. As seen in part I, there is clear evidence of some erosion of the traditional position adopted by Waldock. Moreover, a restrictive competence would result in unacceptable regulatory lacunae in many international areas: lacunae that States are continually seeking to address. A pertinent example of this was the 'Reciprocating States Regime' under which several States, the Federal Republic of Germany, ${ }^{72}$ France $^{73}$ the $\mathrm{UK}^{74}$ the USA, ${ }^{75}$ the $\mathrm{USSR}^{76}{ }^{7} \mathrm{Japan}^{77}$ and Italy ${ }^{78}$ legislated for activities beyond national jurisdiction prior to the finalisation of the LOSC. Then in 1982 France, Germany, the UK and the US published an agreement regulating their claims inter $s e .{ }^{79}$ The aim of these arrangements was to facilitate the exploitation of the mineral resources of the sea-bed outside of the LOSC regime, which looked unduly restrictive and unlikely to enter into force in the near future. These States argued that the regulation was merely a legitimate exercise of authority over their own nationals on the high seas, and that it did not create over the sea-bed exclusive rights enforceable against third States. States outside the regime regarded it otherwise, and argued that it amounted to a disposition of parts of the seabed ${ }^{80}$ In practice, once a State exploits the resources of the Area those resources are effectively removed from the 'res communis pot' which, if not de jure occupation and exploitation, is certainly de facto occupation and exploitation. ${ }^{81}$ It is clear that the jurisdictional distinction that the reciprocating States identified is artificial in practice. It is notable also that that Part XI of the LOSC recognises a category of 'privileged' States in respect

\footnotetext{
${ }^{72}$ Act of Interim Regulation of Deep Seabed Mining, (1981) 20 ILM 393.

${ }^{73}$ Law on the Exploration and Exploitation of Mineral Resources of the Deep Seabed, (1982) 21 ILM 808.

${ }^{74}$ Deep Sea Mining (Temporary Provisions) Act 1981 (1981) 20 ILM 1219.

75 Deep Sea-bed Hard Mineral Resources Act, (1980) 19 ILM 1003.

${ }^{76}$ Edict on Provisional Measures to Regulate Soviet Enterprises for the Exploration and Exploitation of Mineral Resources, (1982) 20 ILM 551.

77 Law on Interim Measures for Deep Seabed Mining, (1983) 22 ILM 102.

${ }^{78}$ Law on the Exploration and Exploitation of Mineral Resources of the Deep Seabed, (1985) 24 ILM 983.

${ }^{79}$ The Agreement concerning Interim Arrangements relating to Polymetallic Nodules of the Deep Seabed, (1982) 21 ILM 950.

${ }^{80}$ See statements made by the Group of 77 in (1985) 6 LOSB 71, 85-6, and (1986) 8 LOSB 36.

${ }^{81}$ The legality of the regime was never tested despite the intractability of the protagonists. Churchill and Lowe note that the international Court of Justice could have decided the matter either way. The Law of the Sea, 3rd ed. (1999) 235.
} 
of the Area, further weakening the rejection of differentiated treaty making competence in respect of the Area. ${ }^{82}$

It is clear that the Area cannot be unequivocally regarded as an objective regime, yet neither can it be said that the regime established does not purport to have some objective effects. The LOSC regime does identify certain general interests of the international community and it attempts to regulate activities in a geographic area in accordance with these. However, the specific implementation of these interests has proved to be highly divisive. It is the specific application of these principles that cast the legitimacy of the regime into doubt. The matter of competence to establish a regime with objective effects is also of importance, and it is apparent that much turns on whether a restrictive or liberal interpretation of competence is adopted.

\subsubsection{High seas fishing}

The 1995 Straddling Stocks Agreement is the most recent in a series of efforts designed to address the problem of over-fishing on the high seas, and its impact on the already fragile state of the world's fisheries. ${ }^{83}$ Traditionally, high seas fisheries have been characterised as a common property resource, meaning that States are free to exploit them subject to only limited constraints, and this has led to well documented problems with attempts to regulate such resources. ${ }^{84}$ The 1995 Agreement goes beyond the general rights and duties

\footnotetext{
${ }^{82}$ These include States having mineral deposits that straddle the Area and their continental shelf (article 142), developing and geographically disadvantaged States (article 148), and States having objects of archaeological or cultural importance lying in the Area (article 149). One should also consider those States who have a privileged position in The Council of the International Sea-Bed Authority, which includes States investing in sea-bed technologies and major exporters of equivalent land based minerals (article 161 of the LOSC and section 3, para. 15 of the 1994 Agreement).

83 Agreement for the Implementation of the Provisions of the United Nations Convention on the Law of the Sea 1982 Relating to Straddling Fish Stock and Highly Migratory Fish Stocks, Doc. A/CONF. 164/38, reproduced in (1996) 34 ILM 876. Hereinafter referred to as the '1995 Agreement'.

${ }^{84}$ In the 'Estai dispute' which arose in respect of Grand Banks fishery, when Canada enacted domestic legislation giving them extraterritorial jurisdiction over foreign vessels in order to protect certain fisheries that straddled the High Seas. Under this legislation a Spanish fishing vessel, the "Estai", was arrested in international waters for breach of the Canadian legislation. This led to diplomatic representations, a call for sanctions and the filing of proceedings against Canada at the International Court of Justice. For more details of the incident see P.G.G. Davies, 'The EC/Canadian Fisheries Dispute in the Northwest Atlantic', (1995) 44 ICLQ 927; D. Freestone, 'Canada and the EU Reach Agreement to Settle the Estai Dispute', (1995) IJMCL 397. Similar problems have arisen in the Behring Sea, the Sea of Okhotsk and regarding the Chilean Mar Presencial. See generally, J.L. Canfield, 'Recent developments in Behring Sea fisheries conservation and management', (1993) 24 ODIL 257; W. T. Burke, 'Fishing in the Behring Sea donut: straddling stocks and the new international law of fisheries', (1989) 16 Ecology Law Quarterly 285; E.L. Miles and D. L. Fluharty, 'US interests in the north Pacific', (1991) 22 ODIL 315; N. S. Miroviskaya and J. C. Haney, 'Fisheries exploitation as a threat to environmental security: the North Pacific Ocean', (1992) 16 Marine Policy 243; Oude Elferink, 'Fisheries in the Sea of Okhotsk high sea enclave - the Russian
} 
set out in the LOSC, by setting out a framework under which regional fisheries organisations are to exercise authority over the certain fish stocks on the high seas. Given the clear mandate to regulate an area beyond national jurisdiction, traditionally subject to flag State jurisdiction only, the question arises to what extent such developments can be imposed on third parties. ${ }^{85}$

There are a number of provisions in the 1995 Agreement that merit attention, given their direct impact on third parties. Thus, article 8(4) states that:

'[O]nly those States which are members of such an organisation or participants in such an arrangement, or which agree to apply the conservation and management measures established by such organisation or arrangement, shall have access to the fishery resources to which those measure apply'.

This provision clearly intends to affect the rights of third States, by removing their freedom to fish in high seas areas subject to a conservation and management arrangement in which these States do not participate. This goes further than previous provisions on high seas fishing, which fall short of making the right to fish absolutely contingent on specific standards of conservation and management. ${ }^{86}$ Mirroring this approach, article 17(1) states that:

'A State which is not a member of a subregional or regional fisheries management organization or is not a participant in a subregional or regional fisheries management arrangement, and which does not otherwise agree to apply the conservation and management measures established by such organisation or arrangement is not discharged from the obligation to co-operate, in accordance with the Convention and

Federation's attempts at coastal state control', (1995) 10 IJMCL 1; C. J. Joyner and P. N. De Cola, 'Chile's Presencial Sea proposal: Implications for Straddling Stocks and the International law of Fisheries', (1993) 24 ODIL 99; J. G. Dalton, 'The Chilean Mar Presencial: A Harmless Concept or a Dangerous Precedent', (1993) 8 IJMCL 397.

85 Article 3(1) of the 1995 Agreement expressly states that it applies to areas beyond national jurisdiction.

${ }^{86}$ E. de Lone maintains that this provision effectively puts an end to the free rider problem caused by the freedom of the high seas. 'Improving the Management of the Atlantic Tuna: The Duty to Strengthen the ICCAT in Light of the 1995 Straddling Stocks Agreement', (1998) 6 New York University Environmental Law Journal 656, at 663-4. Cf. D. Freestone and Z. Makuch, who argue that the obligation is only binding on the parties to the agreement, inter se. 'The New International Environmental Law of Fisheries: The 1995 United Nations Straddling Stocks Agreement', (1996) 7 Yearbook of International Environmental Law 3, at 34. Also E. Franckx, who further argues that as this provision is neither objective nor customary: it is ineffective. 'Pacta Tertiis and the Agreement for the Implementation of the Provisions of the United Nations Convention on the Law of the Sea of 10 December 1982 relating to the Conservation \& Management of Straddling Fish Stocks and Highly Migratory Fish Stocks', FAO Legal Papers Online \#8, July 2000, at http://www.fao.org/legal/ Prs-OL/franckx.pdf. 
this Agreement, in the conservation and management of the relevant straddling fish stocks and highly migratory fish stocks.'

Article 17(2) prohibits non-party States from authorising vessels that are flying their respective flags from engaging in fishing activities in fisheries covered by any regional arrangements. This approach, which implicitly and explicitly creates objective rules, is reinforced by the terminology used throughout the 1995 Agreement. Although article 2(a) specifically defines 'States Parties' the 1995 Agreement often refers to 'States', 'coastal States' or 'flag States', giving the whole agreement a declaratory aspect, rather than simply establishing inter-party rules. Article 5 states that the general principles of conservation and management apply to 'coastal States and States fishing on the high seas', as opposed to merely States parties. This can be taken to suggest that the specific provisions on conservation and management are of general application. A similar interpretation of the enforcement provisions leads to the conclusion that enforcement action may be taken against the vessels of non-party States. Article 18 obligates 'flag States' to uphold the measures established under the 1995 Agreement, and article 33(1) obliges States parties to encourage non-parties to the 1995 Agreement to become parties thereto and to adopt laws and regulations consistent with its provisions. Finally, article 33(2) provides that 'States Parties shall take measures consistent with this Agreement and international law to deter the activities of vessels flying the flag of non-parties which undermine the effective implementation of this Agreement'. Thus, it is possible for contracting States to enforce conservation and management obligations against non-parties as long as this is done in consistency with international law.

Although not explicitly mentioning objective effects, it is implicit that the 1995 Agreement is intended to affect the rights and obligations of third States in a manner consistent with international law. A literal and contextual reading of the provisions suggest that the ratione personae is not limited to States parties, or at the very least there may be a presumption that the 1995 Agreement is intended to have effect beyond the contracting parties. ${ }^{87}$

As article 2 provides, conservation and management is the key objective of the 1995 Agreement:

'The objective of the Agreement is to ensure the long-term conservation and sustainable use of straddling fish stocks and highly migratory fish stocks through the effective implementation of the relevant provisions of the Convention. ${ }^{88}$

\footnotetext{
87 This is borne out by statements in the travaux préparatoires. See the statements on behalf of Australia and the EU, which support measures against vessels acting contrary to regional arrangement, as long as this is consistent with international law. A/CONF.164/L.19 and 20, respectively. See also the Background Paper 8 July 1993, paragraph 109 of which suggests an increased role for regional arrangements in the supervision and enforcement of standards. A/CONF. 164/INF/6.

${ }^{88}$ See also articles $1(\mathrm{~b}), 5,6$ and 7.
} 
Undoubtedly, there is considerable evidence of the general interest of the international community in the conservation and management of the living resources of the sea. ${ }^{89}$ This interest may be just one facet of the more general interest in the conservation and protection of the environment, or it may be an agglomeration of more particular interest in the marine environment, such as the principle of optimum utilisation and the precautionary principle. ${ }^{90}$ Since the Behring Fur Seals Case, conservation of the living resources of the ocean has been one of the primary concerns of the international community. Clearly, there is a long-term interest in providing a sustainable food supply from the oceans and a short-term interest in preventing conflicts arising from competition for limited resources. This interest, framed in terms of the general duty to conserve and manage the living resources of the oceans, is widely recognised as the principal objective of fisheries regulation in numerous legal instruments. ${ }^{91}$ It should also be evaluated in light of the ICJ's suggestion, in the Gabčikovo-Nagymaros Project case, that norms of international environmental law may amount to fundamental norms. ${ }^{92}$ Much of the legitimacy of the 1995 Agreements more radical proposals is predicated on the need to ensure this fundamental objective.

${ }^{89}$ A possible parallel to the regimes established under the 1995 Agreement are the Whaling Sanctuaries established under the International Convention for the Regulation of Whaling 1946, 161 UNTS 72. Under article V, 'The Commission may ... [adopt]... regulations with respect to the conservation and utilisation of whale resources by fixing ... (c) ... open and closed waters, including the designation of sanctuary areas. In 1980 the Indian Ocean Sanctuary was established, covering areas of the high seas. See The Report of the International Whaling Commission (1980), vol. 30, 27. In 1995 the Southern Ocean Sanctuary was established. The amendment to the schedule to the 1946 Convention is reprinted in the Chairman's Report of the 46th Meeting (1995), vol. 45, 28.

${ }^{90}$ In the Southern Bluefin Tuna case, the International Tribunal for the Law of the Sea held that 'the conservation of the living resources of the sea is an element in the protection and preservation of the marine environment'. Order of 27 August 1999, Southern Bluefin Tuna case (New Zealand v. Japan; Australia v. Japan), Requests for Provisional Measures, (1999) 38 ILM 1624, para. 70. The tribunal linked the interest to wider environmental concerns, confirming both its jurisprudential importance and its place in the intricate hierarchy of environmental concerns.

91 Article 1(2) of 1958 Geneva Convention on Fishing and Conservation of the Living Resources of the High Seas, 559 UNTS 285. The 1982 LOSC makes numerous references to it in articles. See preambular paragraph 4, and articles 21(1)(d), 56(1)(a), 61-67, 78(1), 117,118, 119, 123(a), and 277(a). FAO, Code of Conduct for Responsible Fisheries (1995). It is axiomatic that conservation and other environmental concerns, such as sustainability and the precautionary principle, are central to Agenda 21 as adopted at the Rio Conference. United Nations Conference on Environment and Development, Agenda 21: Programme of Action for Sustainable Development. U.N. Doc. A/CONF. 151/26. Available online at http://www.un.org/esa/sustdev/documents/agenda21/index.htm The 1992 Cancun Declaration stressed the need to address factors that undermine the effectiveness of international conservation and management measures, leading to the FAO Code of Conduct for Responsible Fisheries. U.N. Doc. A/CONF.164/INF2/8 (1992). Articles 1, 2 and 6 place conservation at the centre of responsible fishery management regimes.

${ }^{92}$ Op. cit., n. 17. 
The most useful test of the status of the regime is to be found in the practice of States, and their support of or objection to the 1995 Agreement. Unfortunately, there is at present insufficient data to attempt this. ${ }^{93}$ There are, however, other indicators as to the status and future prospects of the 1995 Agreement. Firstly, the 1995 Agreement is part of a systematic approach to fisheries regulation; it is an incremental advance on the policy and laws established under the LOSC, and is articulated in the intervening conferences. As Davies and Redgwell conclude:

'The future law of high seas fisheries will be governed by three levels of largely mutually compatible and reinforcing treaty obligations, ranging from the general provisions of the LOSC through the SSA [1995 Agreement] to the RFOs [Regional Fisheries Organisations]. In practice these will not operate as three separate and conflicting sources of treaty law, since the principles contained at each level may be viewed as simply steps in the concretization of general norms of conservation, management and enforcement. ${ }^{94}$

Most States have participated in its evolution, and throughout there has been a high level of support for the rules and standards so formulated, suggesting a positive outlook. Secondly, the 1995 Agreement is strongly advocated by international organisations with a particular interest and influence in fishing matters, such as the FAO, UNCED, and the UN General Assembly. It has also received widespread approval among publicists, suggesting that it is consistent with internationally recognised standards. ${ }^{95}$ Finally, there is as yet no direct opposition to the rules and provisions of the 1995 Agreement and this would seem to imply that the provisions are generally acceptable. Although the burden lies on the party that is asserting that the regime facilitates the general interest, this should not be problematic in respect of the 1995 Agreement.

Clearly, the arrangements to be established under the 1995 Agreement are intended to have some objective effect, and the issue is rather how such

\footnotetext{
${ }_{93}$ There is a possibility that such a regime will be tested in the Pacific Ocean. The Implementation of the 1995 Agreement under the Draft Convention and Management of Highly Migratory Fish Stocks in the Western and Central Pacific Ocean is likely to be among the first of the regional arrangements set up in accordance with the 1995 Agreement. Reprinted in (2000) 15 IJMCL 121.

${ }^{94}$ P.G.G. Davies and C. Redgwell, 'The International Regulation of Straddling Fish Stocks' (1996) 67 BYIL 199, at 272.

95 See M. Hayashi, 'The 1995 Agreement on the conservation and management of straddling and highly migratory fish stocks: significance for the Law of the Sea Convention', (1995) 29 Ocean and Coastal Management 51; D.A. Balton, 'Strengthening the Law of the Sea: The New Agreement on Straddling Fish Stocks and Highly Migratory Fish Stocks' (1996) 27 ODIL 125; A. Tahindro, 'Conservation and Management of Transboundary Fish Stocks: Comments in Light of the Adoption of the 1995 Agreement for the Conservation and Management of Straddling Fish Stocks and Highly Migratory Fish Stocks' (1997) 28 ODIL 1; L. Juda, 'The 1995 United Nations Agreement on Straddling Fish Stocks and Highly Migratory Fish Stocks: A Critique' (1997) 28 ODIL 147.
} 
effects are to be accounted for. ${ }^{96}$ One explanation is that the regulations of a regional fisheries arrangement can be upheld as obligations undertaken by States parties to the 1995 Agreement. However, this accounts only for States parties to the 1995 Agreement. A second explanation is that third States are bound by rules of customary international law having the same effect. Yet this assumes that the terms of the 1995 Agreement, or a regional arrangement, have parallels in customary international law. This is quite unlikely, in that it assumes that new rules of customary international law in respect of high seas fisheries have emerged in such a short period of time and without a consistent or widespread practice. It may be countered that conservation and management simply amount to a customary obligation, binding upon all States, regardless of its particular form. Although this may be the case, it does not preclude the fact that conservation and management hold the status of a general interest, in the same way that articles 2(3) and (4) of the United Nations Charter do not reduce the general interest in international peace and security to a mere customary norm. In any case, it is unlikely that the principle of conservation and management can be reduced to a customary norm. ${ }^{97}$ The obligations to conserve and manage are by their nature general; they require implementation by more specific norms. ${ }^{98}$ Thus, the 1995 Agreement establishes new norms and standards of behaviour, that are consistent with the existing general interest, and which are opposable to non-contracting States. $^{99}$

The 1995 Agreement is an important development in the regulation of fisheries. It operates as an effective incentive to States to participate in regional fisheries organisations or arrangements. Traditionally, the State who opposes change, whilst other States are pushing for a modification of the

\footnotetext{
${ }^{96}$ The Tribunal on the Law of the Sea has recently issued a judgement on a matter bearing important similarities to the present issue. In The Southern Bluefin Tuna cases the tribunal was requested to decide upon the validity of certain actions under a regional fisheries treaty, supra $\mathrm{n}$. 90. Japan had challenged the jurisdiction of the tribunal on the grounds that the dispute was based on the interpretation of the 1993 Convention for the Preservation of Southern Bluefin Tuna rather than on the LOSC. However, the tribunal held that the conduct of the parties under the 1993 Convention was relevant to an evaluation of their compliance with their obligations under the LOSC. Implicit in this decision is that it is impossible to limit the applicability of the fisheries regime of the LOSC. Wolfrum argues that this flows from the tribunal 'qualifying the Convention on the Law of the Sea as a constitution for the law of the sea matters having priority over international agreements covering certain aspect thereof'. 'The Role of the International Tribunal for the Law of the Sea'; Presentation given at the 23rd Annual Conference, the Centre for Oceans Law and Policy and the UN Food and Agriculture Organisation, Rome, 15th-17th March 2000. Despite the virtue of this ruling the tribunal gives no indication of its reasoning for such a position or the process whereby it could be reached. There is also an important distinction: Japan had voluntarily entered into a regional arrangement, whereas the aim of objective regimes is to hold recalcitrant States to account.

97 See F. Orrego Vicuña, The Exclusive Economic Zone (1989) 244-6.

98 This view is shared by Churchill and Lowe, op. cit., n. 81, at 290.

99 For example, the provisions on the precautionary principle in article 6 go much further than pre-existing obligations.
} 
status quo, finds itself in a stronger negotiating position. Thus, the State resisting the change has much to gain by resisting. If the other States were to fail to secure the agreement of the opposing State, then they run the risk of placing themselves in a disadvantageous position vis à vis that State. Article 8(4) operates to remove this tactical negotiating burden from those States seeking to establish a regulatory regime for sustainable fisheries. Seen in this light, the principal effect of article 8(4) is strategic in that it persuades nonparties to come within the regime, for to do otherwise might result in a greater loss.

\subsection{Environmental protection regimes}

Many environmental issues are transboundary or global concerns, and during the latter part of this century there has been a growing recognition of the fact that States cannot tackle pollution and other environmentally harmful activities individually. The global or transboundary nature of many environmental problems requires a high degree of international co-operation to achieve workable solutions. Customary international law has a limited capacity for creating standards of environmental behaviour because it is incapable of establishing detailed scientific benchmarks, it is usually slow to evolve, and it is often ambiguous in its content. A further problem arises when institutional provisions are desired, such as the establishment of a supervisory or enforcement authority, as custom is ill-suited to such matters. In this respect, treaties are essential to the creation of specific pollution targets and for establishing institutional mechanisms. The need for States to define, implement and enforce transboundary and global standards of environmental protection, which tackle the problem of non-conformity, means that environmental treaty regimes are leading candidates for objective regimes.

\subsubsection{Marine pollution regimes}

Regional pollution arrangements may have objective effects in two circumstances: firstly, where they provide for wider rights for coastal States and impose greater obligations on third parties than does general international law, and secondly, where they extend the geographic competence of coastal States beyond the limits of general international law. ${ }^{100}$

Do any of the regional arrangements provide coastal States with greater jurisdiction than does general international law? The Helsinki Convention for the Baltic Sea of 1974 was the first regional arrangement aimed at regulating all aspects of pollution within a particular marine environment and was

100 General treaties for addressing pollution concerns are not considered; they seek to establish general obligations, as opposed to geographically or territorially distinct regimes. 
a model for subsequent other similar arrangements. ${ }^{101}$ Under UNEP's Regional Seas Programme arrangements have been put in place for the Mediterranean, ${ }^{102}$ the Persian Gulf and Gulf of Oman, ${ }^{103}$ West and Central Africa, ${ }^{104}$ the Red Sea and Gulf of Aden, ${ }^{105}$ the Caribbean, ${ }^{106}$ East Africa, ${ }^{107}$ and the Black Sea. ${ }^{108}$ The geographical scope of these arrangements is generally limited to the jurisdictional waters of the contracting States, either through express provision or by virtue of the limits of the waters involved. The regimes define and harmonise the prescriptive power of the contracting States, and in laying down the powers of the contracting States no greater powers are provided for than are accepted under general international law. The objective impact of these conventions can best be explained by reference to the general obligations inherent in the LOSC, ${ }^{109}$ other international conventions, ${ }^{110}$ or customary international law, and to this extent they are of little value as evidence of objective regimes. If greater powers were to be provided under the regional arrangements then the objective effects of these would have to be considered. This possibility is certainly alive, as the provisions for protection of special areas demonstrates.

Provision is made under article 194(5) of LOSC for the protection and preservation of 'rare and fragile' ecosystems. The notion of such special areas was taken a stage further by the IMO who developed the notion of the Particularly Sensitive Sea Area (PSSA). A PSSA may be defined as:

'An area that needs special protection through action by IMO members because of its significance for ecological or socio-economic or scientific reasons and which may be vulnerable to environmental damage by marine traffic., ${ }^{111}$

\footnotetext{
101 The Convention on the Protection of the Marine Environment of the Baltic Sea 1974, (1974)

13 ILM 544, at 546.

102 The Convention for the Protection of the Mediterranean Sea against Pollution 1976, 1102 UNTS 27.

103 The Kuwait Convention for Co-operation on the Protection of the marine Environment from Pollution 1978, 1140 UNTS 133.

104 The Convention for Co-operation in the Protection and Development of the Marine and Coastal Environment of the West and Central African Region 1981, (1981) 20 ILM 746.

105 The Regional Convention for the Conservation of the Red Sea and Gulf of Aden Environment 1982, (1982) 9 EPL 56.

106 The Convention for the Protection and Development of the Marine Environment of the Wider Caribbean Region 1983, 1988 UKTS 38.

107 The Convention for the Protection, Management and Development of the Marine and Coastal Environment of the Eastern African Region 1985, OJEC C.253 (1986) 10.

108 The Convention for the Protection of the Black Sea against Pollution 1992, (1993) 22 LOSB 54.

109 See Part XII, and in particular articles 192, 194, 210, 211, 212, 220 and 221.

110 For example, MARPOL 73/78, 1340 UNTS 101.

111 Guidelines for the Designation of Special Areas and the Identification of Particularly Sensitive Sea Areas, IMO Assembly Resolution A. 720(17), 6th Nov. 1991, para. 3.1.2.
} 
Under international law coastal States may take only measures consistent with generally accepted international rules or standards, although after consultation with the competent international organisation (IMO) further measures may be taken. ${ }^{112}$ PSSAs have been put into practice only by Australia in respect of the Great Barrier Reef National Park and by Cuba around the Sabana-Camaguey peninsula. In the former, tolls were mooted, raising the spectre of measures far stricter than international standards, and would have begged the question of whether or not such measures could be enforced against third States. One should also consider whether areas straddling the high seas could be subject to stricter regulation than the high seas generally. It has been noted elsewhere that the concept of the PSSA could provide a means of facilitating protective measures necessary to ensure the comprehensive protection of a sensitive area lying beyond unilateral coastal State competence. ${ }^{113}$ The UNEP Regional Seas Conventions offer further support for zones of special protection. In 1995 the Protocol concerning Specially Protected Areas and Biological Diversity was adopted, providing for the establishment of Specially Protected Areas of Mediterranean Importance (SPAMIs). ${ }^{114}$ SPAMIs may be created both within national jurisdiction and on the high seas raising the issue of how such measures would affect the position of third parties and their existing right in the high seas. As are other mechanisms, such measures to enforce the SPAMI provisions are to be in accordance with international law.

The question of regional arrangements encroaching on the high seas arises in two of the regional arrangements, the South East Pacific Convention ${ }^{115}$ and the South Pacific Convention. ${ }^{116}$ These two conventions purport to allow the parties to regulate matters in areas of the high seas, so extending pollution control competence beyond coastal waters. Article 1 of the South East Pacific Convention states that the geographic scope of the agreement includes 'the high seas up to a distance within which pollution of the high sea may affect that area', and article 2(a) of the South Pacific Convention applies to 'enclosed' high seas. Thus measures taken in such areas would clearly affect third parties by permitting the coastal State to impose and enforce more rigorous pollution controls on the high seas than is permitted under general international law. Under article 221 of the LOSC coastal States may take

\footnotetext{
112 See articles 21(2) and 211(6) of LOSC.

113 Report of the International Meeting of Experts on Particularly Sensitive Sea Areas, at the University of Hull 20-21 July 1992, (1992) 26 Marine Pollution Bulletin 9. See also K. Gjerde and D. Freestone, 'Particularly Sensitive Sea Areas - An Important Environmental Concept at a Turning Point' (1994) 9 IJMCL 431, 433.

114 (1995) 6 YbIEL 887.

115 The Convention for the Protection of the Marine Environment and Coastal Area of the South East Pacific 1981, reproduced in Lay, Welch, Churchill and Simmonds, New Directions in the Law of the Sea (1974 - ), Doc. J. 18.

116 The Convention for the Protection of the Natural Resources and Environment of the South Pacific Region 1986, (1987) 26 ILM 41. In force 22 August 1990.
} 
action to counter a maritime pollution incident in the high seas where it threatens the interests of the coastal State. This does not go as far as permitting the legislation and enforcement of rules of a more routine nature, which the two conventions appear to permit. ${ }^{117}$ For example, article 4 of the South East Pacific Convention provides for preventative measures to be taken by the contracting parties, such as rules on dumping, collision prevention, discharges, and operational requirements, at least to internationally accepted standards. Accordingly, there is a potential conflict with the provisions of article 94 of the LOSC and this raises a question of interpretation. A declaration of material jurisdiction over the high seas would be untenable and inconsistent with the limited aims of the conventions. A more reasonable understanding is that the contracting parties are seeking to ensure that the general and particular regional interest in cleaner oceans and safer shipping is maintained in a coherent and consistent manner in the face of jurisdictional inconsistencies. These regimes thus manifest, to some degree, the features of an objective regime, and there are strong parallels with the issue of fisheries regulation considered above.

Regional pollution control regimes suggest a balanced approach to the creation of other objective regimes. They are characterised by the degree of localised or territorial interest at stake in the regime, which in part underpins the authority of coastal States to act in the creation of objective law. This is in accordance with pollution control and environmental protection objectives, which are issues of global concern. Thus regional arrangements correspond with a general interest of the international community, which reinforces the authority of regional States to act. ${ }^{118}$ Despite these 'objective' features, it is arguable that the impact of such regimes might best be explained by reference to other norms of international law, rather than the nature of treaty regime itself. ${ }^{119}$ This demonstrates the vital importance of distinguishing between true objective regimes and other 'objective' treaties that are explained by reference to parallel customary rules or complementary treaty

\footnotetext{
117 This provision reflects the law since the Torrey Canyon incident of 1967, and the international community's general acceptance of the legitimacy of the United Kingdom's action. Other than this exception only flag jurisdiction is permitted in respect of the high seas (Article 92 of the LOSC)

118 A general interest may be derived from specific pollution treaties, such as MARPOL, as well as general environmental instruments such as the Convention on Biological Diversity 1992 and the 1995 Jakarta Mandate on Marine and Coastal Biological Diversity.

119 The International Law Association Committee on Coastal State Jurisdiction relating to Marine Pollution put forward an explanation for the 'objective "effects of certain marine pollution measures at the London Conference. Their approach relies on the notion of rules of reference in framework treaties that point to the further implementation of generally accepted international rules and standards. States can then implement such measures in accordance with the GAIRS, and this can be made opposable to third States that have consented to the original rules of reference. Article 211 of the LOSC is cited as one such rule of reference. See the Final Report of Committee on Coastal State Jurisdiction relating to Marine Pollution (London, ILA, 2000). This approach seems to reflect the same concerns that underpin objective regimes.
} 
provisions. Of course, where treaty provisions differ from custom or other treaties, and this is a distinct possibility in areas which require stricter pollution control regimes, then these provisions must be explained in some other way. Objective regimes would offer a possible basis for this.

\subsubsection{Driftnet fishing}

In July 1989, the South Pacific Forum adopted the Tarawa Declaration in response to the depletion of albacore tuna stocks. ${ }^{120}$ The declaration stated that the use of driftnets in the fishery was "not consistent with international requirements in relation to rights and obligations of high sea fisheries conservation and management and environmental principles'. It further called for a convention to create a zone free of driftnet fishing, and was soon followed by the Wellington Convention for the Prohibition of Fishing with Long Driftnets in the South Pacific. ${ }^{121}$ According to article 1(a) the Convention applies to the coastal waters and high seas within a specified geographic area of the South Pacific, with subsequent provisions seeking to ban the use of driftnets therein. Clearly, the scope of the convention is internal to and beyond coastal State jurisdiction, which has implications for the effectiveness and enforceability of its substantive rules against non-parties, whose nationals fish in areas of the high seas subject to the regime. ${ }^{122}$ Article 3(2) contains a number of provisions that potentially affect the rights of third parties, including preventing the landing of illegal catches, restricting port access to illegal fishing vessels, and the imposition of trade restrictions on States participating in illegal catches. Article 3(3) permits the use of measures against driftnet fishing that are stricter than those required by the convention, thus allowing measures beyond those provided for in article 3(2). These provisions are supplemented by article 4 , which requires that 'each party shall take appropriate measures to ensure the application of this Convention'.

Cumulatively, these provisions appear to curtail the rights of third States where they are acting contrary to the aims and objectives of the regime. However, such an interpretation is tenuous because the obligations are singularly directed at contracting parties. This view is reinforced by article 5, which provides for a consultation process with non-parties in order to draw them into the regime. Two additional protocols were concluded specifically to draw in non-parties, suggesting definite limits to the regime. The regime did not seek to affect the status of the South Pacific, but merely to prevent drift-net fishing therein.

${ }^{120}$ (1989) 14 LOSB 29. See also the 'Castries Declaration' by the Organisation of Eastern Caribbean States, at 28 .

121 (1990) 29 ILM 1454.

122 Notably vessels from non-party States, Japan, the Republic of Korea and Taiwan were apprehended fishing in contravention of the Convention. See the Report of the Secretary General, UN GAOR, 47th session, UN Doc. A/47/487 (1992), at 4 and 9. 
However, almost immediately the regime was reinvigorated by UN General Assembly Resolution 45/225 (1990), which recommended the cessation of large-scale pelagic driftnet fishing in the South Pacific by 1 July 1991 unless conservation and management measures were implemented to prevent the harmful impact of such fishing. ${ }^{123}$ This resolution was reaffirmed in Resolutions 45/197 (1990) and 26/215 (1991), resulting in an end to driftnet fishing. ${ }^{124}$ Indeed, it is notable that, although no States permitting the use of driftnets are a party to the Convention or Protocols, driftnet fishing for tuna has ceased in the zone. ${ }^{125}$ This begs the question - under what obligations are non-parties acting? Hewison suggests that customary rules explain the cease of driftnet fishing, which accounts for the fact that the General Assembly Resolutions are not binding. ${ }^{126}$ However, it is also possible that collectively the Convention and subsequent resolutions have established an objective regime. ${ }^{127}$ Thus Burke et al emphasise, 'nothing in them [the resolutions] mandates that non-compliance is to be sanctioned by terminating the fishery', ${ }^{128}$ highlighting the far-reaching nature of the prohibition on driftnets.

An objective regime has certain inherent advantages in that as a treaty regime it can provide a more comprehensive structure for regulating a complex issue. A major criticism of the prohibition on driftnet fishing is that it is a crude means of dealing with the problem, and that it does not account for actual variations in practice. It does not provide mechanisms for implementing change and for supervising the same. As Burke et al stress, there exists a 'need for an effective governance process that will satisfy general community objectives'. ${ }^{129}$ Such a process simply cannot be provided by a series of resolutions, but instead requires an effective and systematic treaty framework. Although neither custom nor objective regimes are free from criticism, the objective regime approach does at least present certain practical advantages in this respect.

\footnotetext{
123 (1990) 15 LOSB 154.

124 See (1991) 17 LOSB 7, and (1992) 20 LOSB 14 respectively.

125 A. Bergin, 'Political and legal control over marine living resources - recent developments in South Pacific distant water fishing', (1994) 9 IJMCL 289, at p. 301.

${ }^{126}$ G.J. Hewison, 'The legally binding nature of the moratorium on large-scale high seas driftnet fishing', (1994) 25 JMLC 557.

${ }^{127}$ In either case it would be difficult to ascertain with which norms a State is complying, be it customary norm or an objective treaty regime. If a customary rule exists then it would have to account for its apparent conflict with existing norms in respect of high sea fishery resources. See the Asylum case, ICJ Rep. 1950, 266 at 276-77.

128 W.T. Burke, M. Freeberg and E.L. Miles, 'United Nations resolutions on driftnet fishing: an unsustainable precedent for high seas and coastal fisheries management', (1994) 25 ODIL 127, at 172.

129 Ibid. 170.
} 


\subsubsection{Ozone depletion}

The principal instrument regulating activities harmful to the ozone layer is the Montreal Protocol on Substances that deplete the Ozone Layer. ${ }^{130}$ It regulates an area of common concern to all States, the protection of which is in the general interests of all States. Such an interest incorporates a variety of concerns both environmental and relating to human health. At an early stage it was realised that the failure of the regime to achieve widespread ratification would lead to economic disparities between parties and non-parties, thus undermining the objectives of the regime, so steps were taken to try and address the problem of recalcitrant States, free riders and the problem of 'hold-outs'. Unless non-parties were addressed, the convention would simply result in the reallocation of CFC production from States parties to non-parties. This would further deter potential signatories from acceding to the protocol because it would result in their being placed at an economic disadvantage vis à vis non-parties.

The Montreal Protocol attempts to deal with these problems by utilising trade sanctions. Article 4(1) places parties under an obligation to 'ban the import of controlled substances from any State not party to this Protocol' within one year of entry into force of the Protocol, and article 4(2) contains a similar control in relation to exports. Article 4(5) places a duty on States to 'discourage' trade in technology for producing and utilising controlled substances, while article 4(6) controls the granting of aid if such aid would lead to the production of controlled substances. Cumulatively, these provisions may have an affect on third parties, for although they do not directly impose obligations on third parties they do have considerable indirect effects. Quite clearly, this does not amount to the level of obligation that an objective regime would seek to effect, but it must be remembered that the success of such a regime is commensurate with the degree of support that it can attract, and with the articulation of a general interest. Palmer describes the approach to the atmosphere as 'slicing the salami thinly', i.e., the use of small incremental measures to ensure widespread support. ${ }^{131}$ This reflects the acutely sensitive nature of the interests that would be affected by a regime protecting the atmosphere since stronger measures would simply have pitted the protection of the atmosphere against the commercial interests and freedoms of States. The protection of the atmosphere may in the future evolve into an objective regime if such political issues can be resolved, and if the increasing perils of inaction are recognised.

The Protocol is the genesis of a new approach to environmental protection at the international level. It has already made inroads into consent by adopting procedural rules based on majority, rather than unanimous, decision-making. This has been reinforced by the Hague Declaration, which calls for a 'new

130 (1987) 26 ILM 1550.

131 Palmer, op. cit., n. 15, at 274. 
institutional authority ... responsible for combating further global warming', again operating beyond the rule calling for unanimous agreement. ${ }^{132}$ Palmer identifies three challenges for global environmental problems: setting rules, monitoring and verifying compliance, and settling disputes in an authoritative and binding manner. ${ }^{133}$ These problems can be addressed adequately only in the form of a treaty; a treaty which will invariably establish obligations erga omnes. Although the ozone regime is not yet truly objective, if it and other areas of the environment develop in a way that effectively protects the environment, then they may certainly require evaluation as objective regimes in the future.

\subsection{Neutrality and demilitarisation}

In this area, perhaps more than any other, there is clear support for the notion of objective regimes. Under the Congress of Vienna, Belgium had certain obligations as a frontier fortresses imposed on it by Great Britain, Austria, France and Russia. ${ }^{134}$ Subsequently, in 1831 the Treaty of London imposed neutrality on Belgium. ${ }^{135}$ In 1856 France, Great Britain and Russia adopted the Aaland Islands Convention, which provided that 'the Aaland Islands shall not be fortified, and that no military or naval base shall be maintained or created there'. ${ }^{136}$ The objective character of this provision was recognised by the League of Nation's Committee of Jurists in the Aaland Islands Case ${ }^{137}$ Elsewhere, Switzerland was subjected to permanent neutrality, a status that has not since been contested. ${ }^{138}$ The neutrality of Austria is another example in point, which has entered the ordre public of Europe. ${ }^{139}$ Mention has already been made of the Antarctic Treaty. In 1962, the Declaration on the Neutrality of Laos was issued and has been effective since. ${ }^{140}$ Similarly, the Cambodian Settlement has been respected. ${ }^{141}$ Apart from agreement on the general status of States, specific regimes have been provided for international waterways such as the Kiel Canal ${ }^{142}$ and Panama

\footnotetext{
132 The Hague Declaration on the Environment, (1989) 28 ILM 1308, at 1310.

133 Palmer, op. cit., n. 15, 283.

134 See [1964] YILC vol. II, 30.

135 Ibid.

136 BFSP (1855-1856), London 1865, 24.

137 Supra n. 52.

138 Ibid.

139 See J. Kunz, ‘Austria’s Permanent Neutrality' (1956) 50 AJIL 418.

140456 UNTS 301.

141 (1992) 31 ILM 180.

142 Under the Treaty of Versailles the Kiel Canal shall be 'maintained free and open to the vessels of commerce and war of all nations at peace with Germany'.
} 
Canal. ${ }^{143}$ All of these arrangements provide a core of evidence for objective regimes.

Where such arrangements are within the boundaries of a particular State, they may be explained according to principles of sovereignty, territorial integrity and political independence of States, respect for which would support a status of neutrality. However, other States, as in the case of the Aaland Islands or Belgium, often impose such arrangements, and so this explanation fails. More recently, the Security Council of the United Nations has imposed safe havens, enclaves and demilitarised zones on Iraq, which again cannot be explained on the basis of sovereignty. ${ }^{144}$ In such cases, the instrument creating the territorial arrangement will invariably have objective effects, certainly against the State subject to the arrangement, and arguably against States not party to the arrangement. The objective effect of these arrangements can be explained according to the theory of objective regimes.

Neutrality and demilitarised zones are also valid when established in extraterritorial areas. This is evidenced by the general acceptance of the Antarctic and Outer Space regimes. The Tlateloco Treaty of $1967^{145}$ and Treaty of Raratonga of $1985^{146}$ establish nuclear free zones in the Pacific and Atlantic oceans off Latin America and in South Pacific respectively. The Indian Ocean Zone of Peace Declaration 1971 establishes a more comprehensive demilitarised zone. ${ }^{147}$ A Second Zone of Peace, for the South Atlantic, followed suit in $1986 .{ }^{148}$ By providing for demilitarisation in areas including the high seas such agreements will inevitably affect the freedom of third parties as provided for under general international law. Although not every State respects such arrangements, and some uncertainty as to whether specific provisions of the Zone of Peace are de lege ferenda rather than lex lata, the establishment of such zones is beyond doubt. Moreover, a majority of States would appear to support the existence of such zones. ${ }^{149}$

Doctrinal support for objective regimes is quite unanimous in this area, with writers from $\mathrm{McNair}^{150}$ to Subedi ${ }^{151}$ categorically supporting their existence. Waldock was quite certain about the objective status of such arrangements during the ILC's discussion of the subject:

\footnotetext{
143 Article 2 of the Panama Canal Treaty provides for the Canal being 'open to peaceful transit by the vessels of all nations', (1977) 16 ILM 1022

144 See generally, Subedi, op. cit., n. 36.

145634 UNTS 281.

146 (1985) 6 LOSB 24.

147 General Assembly Resolution 2832 (XXVI) of 1971.

148 Declaration on the South Atlantic as a Zone of Peace and Co-operation, General Assembly Resolution $41 / 11$ of 1986 .

149 At the 1983 Summit Conference of the Non-aligned Countries, a declaration was issued stating that military presence in the zone constitutes a violation of the Indian Ocean Zone of Peace. See UN Doc. A/AC.159/L.55/Add. 1.

150 Op. cit., n. 4, at 255.

151 Op. cit., n. 8.
} 
'It may freely be conceded that certain kinds of treaties, e.g. treaties creating territorial settlements or regimes of neutralisation or demilitarisation, treaties of cession and boundary treaties, either have or acquire an objective character'. ${ }^{152}$

Even Roxburgh, who argues that treaties cannot by their inherent nature be objective, concedes that neutrality settlements should be respected by nonparty States. ${ }^{153}$

Quite clearly State practice and doctrine support objective regimes that facilitate international peace and security. The widespread acceptance of this type of objective regime suggests a direct correlation between the universal acceptance of peace and security as a keystone of international society, on the one hand, and the legitimacy of the particular regimes that facilitate this on the other. In the past this has justified the intervention of 'Great Powers' in the affairs of lesser States in Europe to maintain order and stability. The same interest has, more recently, justified the exercise of a similar power by the United Nations. In each case the intention that the regime has effect beyond the parties to it was unequivocal, and respect for the regimes has been forthcoming. This is despite the difficulties in attributing competence to the acting parties, and the manifest conflict with the pacta tertiis rule. Presumably, this can only be countenanced by according a higher normative weight to the general interest, which would then appear to outweigh the countervailing considerations of sovereignty and consent.

\subsection{Conclusion}

Objective regimes are undeniably the product of a need to adapt the lawmaking process to accommodate changing social, political and environmental demands. The concept is supported by lucid and persuasive arguments that conceptualise international law in a new light, away from the restrictive trappings of absolute sovereignty, consent and bilateralism. Such perspectives are not merely rhetoric or aspiration, but are supported by State practice and by the decisions of international tribunals. A dogmatic rejection of the role of objective regimes prioritises the misplaced concerns and values of our international system.

In the area of neutrality and demilitarisation there is strong evidence of the existence of objective regimes. The Antarctic, Deep Sea-Bed and Outer Space all manifest some objective characteristics and are arguably objective regimes. Finally, there are a number of environmental regimes that manifest objective characteristics, and although they may be only tenuously hailed as objective regimes, it is likely that objective environmental regulation will continue to develop in this direction. As has been shown the practice arises

${ }^{52}$ [1964] YILC, vol. II, 26.

153 Roxburgh, op. cit., n.4, at 58. 
in three principal areas: areas that require a high degree of international cooperation to achieve effective regulation, areas requiring a high degree of stability, such as boundaries or rights of communication, and in areas of common interest, such as the environment. The regulation of such areas has been consistently hampered by limitations in customary law and a contractual approach to treaties. It requires a new way of law making; objective regimes offer just such an opportunity.

\section{CRITERIA FOR AN OBJECTIVE REGIME}

If objective regimes are to make the transition from de lege ferenda to lex lata, or to gain wider acceptance, then it is necessary to make sense of this body of practice, and remove any doubt as to the nature, scope and utility of objective regimes. Some parameters must be established for the concept. From the above review of practice, the following factors have been identified. There must be an intention by the parties to create such a regime, the regime must be territorial, the parties must have a competence in respect of the territory or an interest in the creation of the regime, and the regime must be in the general interest of the international community. ${ }^{154}$ These will be examined in turn.

\subsection{Intention to create such a regime}

The requirement of an intention to create an objective regime is axiomatic, for without such intention there should be no question of the treaty having anything other than incidental effects on third parties. As the Permanent Court noted in the Free Zones case, 'stipulations pour autrui are not to be lightly presumed'. ${ }^{155}$ Thus intention serves to weaken the presumption in favour of the pacta tertiis rule. ${ }^{156}$ As the pacta tertiis rule is fundamental, and objective regimes are an exception to it, intention of the parties is an important indicator of the inapplicability of the pacta tertiis rule in particular circumstances. It is also important in order to distinguish objective regimes from treaties that only incidentally affect third States interests.

As has been shown above, an intention to establish an objective regime could be made out in the Antarctic Treaty, the Outer Space Treaty, the 1995 Agreement, and the Zones of Peace, but was less clear in regimes such as the deep sea-bed and the environmental regimes. Such an intention is often

\footnotetext{
154 Similar criteria are adopted by Mosler and Klein. H. Mosler, 'The International Society as a Legal Community' (1974-IV) 150 RdC 11, at 235. Klein, op. cit., n. 6.

1551932 PCIJ Ser. A/B, No 4, at 147-8. See also the North Sea Continental Shelf cases, ICJ Rep. 1969, 3 at 25-6.

156 Such an approach was adopted by Fitzmaurice, [1960] YILC, vol. II, 77.
} 
disputed and so it is not the requirement for intention that is problematic, but rather the matter of identifying its existence in any given situation. As objective regimes are treaties, the question of whether or not the parties to an agreement intend it to have objective effect is a matter of treaty interpretation. ${ }^{157}$ Accordingly, a number of factors, including the actual language and emphasis of the agreement, the practice of the parties, and the object and purpose of the agreement, are to be taken into account in order to determine the proper interpretation of the instrument. The result of such investigation must reveal a clear and unambiguous intention to create a regime that has erga omnes effect and also that is in the general interest.

The requirement of intention has a good deal of currency in the academic literature in support of objective regimes. Klein argues that it is essential that the parties to the treaty demonstrate an intention to create a treaty with erga omnes effect, ${ }^{158}$ and Waldock makes it a key requirement in his draft article on treaties. ${ }^{159}$ Subedi argues that intention is of crucial importance, stating that:

'[T]he intention of the parties to create legal relations, rather than the form in which such intention is expressed, is important. If such intention can be established, no matter what form may be adopted in expressing that intention, the form used can be regarded as being capable of creating legal relations between States.'

He continues to argue that such an intention to create a territorial settlement could be expressed by resolutions of the UN Security Council, for example Resolution 687 (1991). ${ }^{160}$ However, intention alone cannot be the sole criterion for an objective regime, for it reflects a contractual approach to treaties and such an approach is quite inimical to objective regimes. Although it is a necessary element in identifying the nature of the regime, and provides the motive force behind the emergence of the regime, it must be accompanied by other criteria.

\footnotetext{
157 Arguably, treaties are not the only means of establishing an objective regime. Subedi makes out a strong argument in favour of other instruments such as General Assembly and Security Council resolutions as being capable of establishing objective regime. Supra n. 8, 218-222. Such canons of construction are to apply as far as possible to declarations or resolutions of international organisations where they precipitate an objective regime.

158 Klein, op. cit., n. 6, at 352.

159 He states that 'a treaty establishes an objective regime when it appears from its terms and from the circumstances of its conclusion that the intention of the parties is to create in the general interest general obligations and rights relating to a particular region ...', [1964] YILC, vol. II, $26 \mathrm{ff}$.

${ }^{160}$ Op. cit., n. 36, $194-195$.
} 


\subsection{The regime must regulate the status of the territory}

A review of practice and doctrinal opinion quite clearly demonstrate the requirement that the regime must be territorial. Apart from trite definitional issues as to 'territory' with which the earlier considerations of the Antarctic, the Deep Sea-bed, Outer Space, the High Seas, and the Global Atmosphere presented us, the territorial nature of objective regimes in State practice is unequivocal. International Settlements, such as the Aaland Islands Convention $^{161}$ and German Reunification ${ }^{162}$ are objective territorial regimes; similarly, there are internationalised territories, such as Danzig ${ }^{163}$ and Berlin. ${ }^{164}$ Equally, boundary treaties have been upheld by the PCIJ ${ }^{165}$ and the $\mathrm{ICJ}^{166}$ as territorial regimes with objective effects. This practice is clearly supported by doctrine. McNair, ${ }^{167}$ Kunz, ${ }^{168}$ Mosler, ${ }^{169}$ Klein, ${ }^{170}$ Crawford, ${ }^{171}$ and Greig ${ }^{172}$ have all highlighted, or laid emphasis on, the requirement of a territorial factor within the regime.

Requiring the objective regime to be a territorial regime means that it can be distinguished from general law-making treaties. To abandon the territorial element would suggest that States could produce law-making treaties regulating the general conduct of States, which is clearly an untenable claim. Territoriality places a necessary and functional limitation on the prescriptive powers of States. In practice, this distinction might be a subtle one. If the Tlateloco Treaty is contrasted with the Moscow Test Ban Treaty ${ }^{173}$ this becomes apparent. Whilst the former is an undertaking not to use nuclear weapons in a specific geographic zone, the latter merely establishes general

\footnotetext{
161 The Committee of Jurists established by the League of Nations considered that 'the convention in reality has a much more extended bearing', op. cit., n. 52, at 17.

162 The Treaty on the Final Settlement with respect to Germany, (1990) 29 ILM 1187.

163 Free City of Danzig and the ILO Advisory Opinion, 1930 PCIJ Ser. B, No. 18. See also International Status of South West Africa Advisory Opinion, supra n. 39.

164 The internationalisation of Berlin after WWII remained effective until German reunification in 1990.

165 See the Free Zones of Upper Savoy and the District of Gex case,1932 PCIJ, Ser. A/B, No. 24 and No. 46.

166 See the Temple of Preah Vihear case, ICJ Rep. 1962, 6.

167 McNair was principally concerned with dispositive or real treaties. Op. cit., n. 4, at 255 et seq.

168 Kunz considered that the permanent neutrality of Austria created 'a legal situation valid erga omnes', op. cit., n. 139.

169 Op. cit., n. 154.

170 Op. cit., n. 6.

171 ' $[\mathrm{M}]$ ultilateral territorial settlements may well possess certain special features as a matter of general international law', J. Crawford, The Creation of States in International Law (1979), 318.

172 '[I]t has long been accepted that a treaty (often termed a 'dispositive treaty') can create a special territorial regime which goes beyond a purely contractual relationship', D. W. Greig, International Law 2nd ed. (1976).

173 The Nuclear Test Ban Treaty, 480 UNTS 43.
} 
obligations not to test weapons on the high seas. This is of crucial importance in practice.

Territory also distinguishes the objective regime from treaties of an institutional nature, such as the United Nations Charter. Klein considers that it is important to do this, although he concedes that this approach seems somewhat artificial. ${ }^{174}$ The objective status of the UN is usually treated as a question of legal personality, and dealt with according to a functional test, which demands that the UN has such powers as are necessary to carry out its given mandate. ${ }^{175}$ Although the objective status of the UN can best be explained by reference to theories of recognition or tacit acceptance, it is interesting to note that the objective status of the United Nations cannot derive from customary law, given the institutional nature of the Charter. The objective personality of the UN must derive from some quality of its constitutional nature, and so has strong parallels with the concept of objective regimes. It is also notable that a functional test could be applied equally readily to objective regimes. Thus, if such territorial treaties were not to exert objective effects then their purpose would be frustrated. The objective force of the regime is arguably a necessary and functional extension of its purpose.

It must be noted that the territorial element does not require that third parties are actively using the territory in order to come under the scope of the regime. Fitzmaurice used this 'active' or 'automatic entailment' approach as it seemed to provide logical support for 'effects in detrimentum'; that if a third party enjoys the use of some territory, then it must conform to any conditions that were laid down in respect of such use. ${ }^{176}$ However, such a distinction appears artificial in light of actual State practice. Waldock, as the subsequent Special Rapporteur, rejected this approach, denying that any active element is necessary for the existence of third party rights or obligations. He used the example of the Antarctic Treaty to illustrate his point:

'The Antarctic Treaty, for example, provides in article 2 for a right of use for scientific investigation; but in article 1 it also provides for a demilitarisation regime which goes beyond, and is independent of, the use of Antarctica for scientific purposes. ${ }^{177}$

Waldock's view is more persuasive given the practical problems that are presented by the use of areas such outer space or the deep-sea bed. Also, in

\footnotetext{
174 'It is, however, interesting to note that the doctrinal deliberations made by the International Court of Justice in the Advisory Opinion Reparations for Injuries Suffered in the Service of the United Nations have parallels in the literature on status treaties'. Klein, op. cit., n. 6, at 352.

175 See Brownlie, op. cit., n. 4, chapter XX.

176 Draft article 14, [1960] YILC, vol. II, 79, and the accompanying commentary at 92 et seq.

177 Ibid. 29. He also refers to the Suez Canal Convention and the Montreux Convention in which the nature of obligations is distinct from the use of the territory.
} 
respect of other areas such as the ozone layer or the atmosphere, individual use is difficult, and perhaps impossible, to establish and quantify.

Finally, it is important to note that one can distinguish between two broad types of territorial regime. On the one hand there are territorial regimes falling under the exclusive control of States, and on the other there are those territorial regimes which relate to international areas, or areas subject to the interest of all States. Such a distinction does not affect the essential quality of the regime as an objective territorial regime, but it does affect how States' competence to act in respect of the area is assessed. In those areas subject to exclusive control, the question of objective regimes may be superfluous, for the principle of territorial sovereignty establishes that the competent State has over matters within its geographic jurisdiction absolute discretion, which other States must respect. This issue becomes acute only when the international community regards a use of some 'domestic' territory as a vital privilege and desires to protect the privilege. ${ }^{178}$ Extra-territorial regimes raise even more acute questions because no exclusivity of interest can be asserted beyond States' borders. In such areas a relative parity exists between States, although matters such as proximity, economic, social, political, and even ethical concerns may affect this; neither will interests always be complementary. In such situations those States establishing the objective regime must be capable of demonstrating some special authority or competence for their action, and it is to this question that we now turn.

\subsection{The States Parties must have some competence to act or an interest in the regime}

There is a fundamental connection between the States parties to an objective regime and the legitimacy of that regime. If the regime is to be effective then the parties must demonstrate some competence to act, or at least some particular interest in the creation of the regime. Competence to act is a persistent, if somewhat ambiguous, feature of State practice, and it is generally required in doctrinal considerations of the issue. As is the territorial requirement, it is an important functional limitation on the parties ability to prescribe rules with erga omnes effect. Competence to act has been defined in a number of ways. Firstly, it has been defined in terms of strict territorial competence, thus the contracting parties must have the territorial competent State among their number. Secondly, there is the 'Great Powers' theory, which provides competence to a group of influential States, capable of imposing their will on other States. Finally, there is the liberal approach to competence, which turns on the manifestation of actual State interest rather than the formalistic requirement of territorial competence.

178 Such situations may arise in respect of international waterways, international straits, rights of transit to the sea and rights of air passage. 
Strict territorial competence has been the most commonly relied upon basis for competence to create an objective regime. State practice, such as Austria's unilateral declaration of neutrality, ${ }^{179}$ or the Lateran Treaty establishing the neutrality of the Vatican City reflect this approach. ${ }^{180}$ Accordingly, Klein requires that parties must have a territorial competence with regards to the subject matter of the treaty that non-party States do not have. ${ }^{181}$ This reflects Waldock's draft article 63, which provides that:

\begin{abstract}
'A treaty shall establish an objective regime ... provided that the parties include among their number any State having territorial competence with reference to the subject matter of the treaty'. ${ }^{182}$
\end{abstract}

Arguably, this reliance on territorial competence flows from a narrow conception of objective regimes as merely dispositive treaties, which in turn reflects traditional notions of sovereignty. ${ }^{183}$ Such a preoccupation with territorial competence is something of an anachronism given that developments in international law have demonstrated States' interests, or rights and obligations, are no longer concomitant with their territorial limits. Accordingly, one must take account of such developments when considering the issue of States capacity to create regimes that settle matters erga omnes. Klein's approach results in his having to distinguish treaties in respect of res nullius (high seas, outer space), a distinction that seems to ignore the criterion of general interests and runs counter to his argument that the existence of a general interest is decisive. ${ }^{184}$ This failing suggests that we must consider the other approaches to competence.

Another way of ascribing competence to act is the 'Great Powers' theory, whereby certain powerful nations were attributed with authority to act in the interests of all nations. There is considerable early State practice in support of this approach, for example, the Peace of Westphalia, the Treaty of Utrecht, and the Treaty of Versailles. It was also recognised in the Aaland Islands case, where the Committee of Jurists stated that:

'An examination of the political conditions in which this agreement was entered into shows that the convention in reality has a much more extended bearing ... the

\footnotetext{
179 Kunz, op. cit., n. 139.

180 (1958) 78 Acta Apostolicae Sedis 522.

181 Op. cit., n. 6, at 21 et seq.

182 Op. cit., n. 32.

${ }^{183}$ In the Island of Palmas case, Judge Huber stated 'the exclusive competence of the State in regard to its own territory ... (is made)... the point of departure in settling most questions that concern international relations.' (1928) 2 UNRIAA 829, at 838. In the North Atlantic Coast Fisheries case the tribunal stated that 'one of the essential elements of sovereignty is that it is to be exercised within territorial limits', (1910) 11 UNRIAA 167, at 180. See also the Corfu Channel case (Merits), ICJ Rep. 1949,4 at 35

184 Klein, op. cit., n. 6, at 352.
} 
provisions settled upon in Paris between the Powers and Russia went beyond the limit of purely Swedish interests'. ${ }^{185}$

More recently, McNair took time to elaborate on the position of the 'Great Powers' in his separate opinion in the South West Africa Advisory Opinion:

'From time to time it happens that a group of great Powers, or a large number of States both great and small, assume a power to create by a multi-partite treaty some new international regime or status, which soon acquires a degree of acceptance and durability extending beyond the limits of the actual contracting parties, and giving it an objective existence. This power is used when some public interest is involved, and its exercise often occurs in the course of the peace settlement at the end of a great war.' ${ }^{186}$

Such practice leads De Visscher to conclude that a treaty between the 'Great Powers', concerning the preservation of peace, could create a legal situation not confined to the contracting parties. ${ }^{187}$

Despite such apparent support the 'Great Powers' theory has some critical defects. It appears only to pertain to periods of great upheaval, such as the aftermath of a war when the need for political stability is paramount, and so does not properly account for other instances of objective regimes during peace time; nor has it been used to explain State practice in the period since the end of World War II, suggesting that it may be obsolete. It also fails to account for regional action by 'lesser States', or the open participation of States in extra-territorial regimes, such as the Zones of Peace or Antarctica. Finally, and most crucially it is quite incompatible with the fundamental notion of the equality of all States, a fundamental precept of contemporary international law. Subedi has recently argued that such an authority may now rest with the United Nations. ${ }^{188}$ This is an interesting approach given the apparent monopoly held by the UN over such collective action; any group of powerful States making such permanent settlements in the future would be highly controversial. Of course, this has been cast into doubt by the recent invasion of Iraq, which was mounted outside of the UN Charter mechanisms.

The liberal approach is adopted by Mosler, who describes an international regime as:

'[A] treaty between States which does not create an international organisation but rather regulates the position of a territory or an object of common use such as water

\footnotetext{
185 Op. cit., n. 52, at 17

186 ICJ Rep. 1950, 132.

187 C. de Visscher, Theory and Reality in Public International Law (1957), 258-63. (translated by P.E. Corbett)

188 Op. cit., n. 36.
} 
(including the high seas and seabed), air and outer space, or means of communication. ${ }^{189}$

No restrictions are placed on the competence of the parties, and instead he emphasises the importance of the regime for international society as a whole, and that it should be respected for that reason. ${ }^{190}$ The focus is on a territory, or object of common use, and it thus reflects actual interests, rather than abstract jurisdictional notions or arbitrary accounts of de facto power. Most importantly, this account of competence is in accordance with the vagaries of State practice. The 'Great Powers' theory might be regarded as a primitive account of this approach. It also proves to be quite compatible with Subedi's thesis.

The competence to act thus must correspond to the acting States' interests and, more importantly, to the interests of the international community. Such a coincidence of localised and community interests will typically arise in respect of regional arrangements, suggesting that they might be the most appropriate candidates for objective regimes. This is not to say that global regimes could not become objective regimes, but only that it will be more difficult to establish a particular competence or authority to act in such instances. This perhaps accounts for the difficulties in establishing regimes for the protection of the global atmosphere. To some extent the number and importance of participants in the regime might remedy such difficulties, because these factors have a patent bearing on the political legitimacy of the regime. Thus, the participation of those States with territorial claims, or active interests in Antarctica was essential. Similarly, the participation of pioneer investors, exporters of certain minerals, developing and disadvantaged States, along with relevant coastal States would be necessary for the Deep Seabed regime to have legitimacy. ${ }^{191}$ There need not be universal participation. The issue is relative and each case should be assessed on its own merits. Thus, where the regime has a purely regional scope, then the participation of those parties in the region is determinative, as is the case in respect of Zones of Peace.

An interesting approach to the issue of competence arises in the 1995 Agreement, where competence to prescribe for high seas fisheries appears to be based on the tripartite grounds of territorial competence, preferential rights, ${ }^{192}$ and the "compatibility principle. ${ }^{193}$ The role of regional fisheries

\footnotetext{
189 H. Mosler, op. cit., n. 154154.

190 Ibid.

191 Such States enjoy a privileged position by virtue of the LOSC and the 1994 Agreement. See, for example, articles 140, 142, 148149 and 150 of LOSC.

192 The idea of preferential interests was controversially put forward by the ICJ in the Fisheries Jurisdiction case, ICJ Rep. 1973, 3. More recently, certain States have advocated such interests. Orrego VicuÑa notes that Chile and the United States have put forward such claims when fish stocks are at risk, The Changing International Law of High Seas Fisheries (1999), 121. Canada and the
} 
arrangements in facilitating co-operation in respect of high seas fisheries is also generally recognised. This suggests a pragmatic approach to competence that takes account not only of legal factors, but also of key socio-economic and political concerns. In areas where the degree of competence is ambiguous, shared or practically indivisible, a flexible approach to competence has patent advantages.

There is a need to supply States with a competence to create objective rights. Historically, territorial competence determined the scope of a States' capacity to make territorial settlements with objective effect, with the exception of settlements made by the 'Great Powers'. However, contemporary international law regulates many areas where strict, or exclusive, territorial competence does not exist, expanding the range of matters in which States may enjoy legal privileges or interests. These interests tend to relate to use rights rather than to exclusive legal title, for which must be accounted in the prescriptive process. If we are to recognise them and thus to avoid lacunae or conflicts, then it is advisable to apply a more liberal definition of competence. With such an approach there is no hard and fast rule that determines the level of the authority necessary to establish an objective regime. There exists between absolute territorial competence, at the one end, and negligible legal interest at the other a spectrum along which most States rights are positioned. It is suggested that as a State tends towards the latter, the more difficult it will be to establish a legitimate objective regime, whereas the former makes the establishment of an objective regime more likely; each case should be assessed on its merits. Finally, in any given case, a variety of circumstances must be taken into account, including the number of States participating in the regime, the interest they have in the regime, the existing regulatory structure, the impact on third States, and the general interest in the regime. Of these factors the last has critical importance.

\subsection{The regime must serve a general interest of the international community}

Although both the absence of an international legislature and the consequent demand for some form of coherent global prescriptive process are persuasive reasons for an exception to the pacta tertiis rule, they provide a

\footnotetext{
Russian Federation adopted a similar position during the negotiation of the 1995 Agreement. See the Letter dated 27 July from the alternative chairman of the Russian Federation, A/CONF.164/L.27, and the List of Issues of 4th June 1993, A/CONF. 164/L. 5 respectively.

193 According to this principle the resources in areas under national jurisdiction and the high seas should be regulated in a consistent manner. Thus article 7(2) of the 1995 Agreement states that: 'Conservation and management measures established for the high seas and those adopted for areas under national jurisdiction shall be compatible in order to ensure the conservation and management of straddling fish stocks and highly migratory fish stocks in their entirety'. (Emphasis added)
} 
weak conceptual and juridical basis for objective regimes. The fundamental nature of the pacta tertiis rule demands that a coherent explanation of objective regimes have both a conceptual and legal basis. The common thread running through the above examples of objective regimes is that they all purport to serve the general interests of the international community. It is this core concept of 'general interests' that provides the legitimacy and legal basis for objective regimes.

State practice shows that, as in the case of the protection of the ozone layer or the deep sea-bed, uncertainty as to the general interest is critical. Emphasising this point, Klein states that the:

'[D]ecisive criterion for establishing whether an objective regime valid erga omnes exists, is whether or not a general interest is served. ${ }^{194}$

Of course, the authority of this proposition depends on whether international law recognises a category of general interests. Klein affirms that such a category does exist, and argues that international law already recognises the concept of general interests in the form of ius cogens and ordre public. ${ }^{195} \mathrm{His}$ is not an isolated claim, and there is further support for it in academic literature. Lauterpacht argued that:

'[A]s international society is transformed into an integrated community, departure from the accepted principle (pacta tertiis) becomes unavoidable, in particular in the sphere of international peace and security. ${ }^{196}$

He cites both Article XXVII of the League Covenant and Article 2(6) of the United Nations Charter in support of this trend, and continues:

\begin{abstract}
'Both the Covenant of the League of Nations and the Charter of the United Nations, must therefore be regarded as having set a limit, determined by the general interest of the international community, to the rule that a treaty cannot impose obligations upon States which are not parties to it. ${ }^{197}$
\end{abstract}

Phillimore writes of treaties which incorporate "by the common consent, express or tacit, of all States concerned in its assertion and maintenance a great public principle into the International Code'. ${ }^{198}$ Westlake refers to treaties that are 'a part of the permanent system of Europe, only liable to be

\footnotetext{
194 Klein, op. cit., n. 6, at 352. (Emphasis added)

195 Ibid. 353

196 H. Lauterpacht, Oppenheim's International Law, Vol. I, 8th ed. (1955), 528.

197 Ibid. 529. (Emphasis added) This process was acknowledged in the Reparations for Injuries Suffered in the Service of the United Nations case, where the Court confirmed the objective legal personality of the United Nations. ICJ Rep. 1949, 174.

198 International Law, vol. iii (3rd ed.), 796.
} 
affected by one of those great revolutions which disturb that system at long intervals. ${ }^{199}$ McNair goes even further: noting the practical consequences which flow from the recognition of this principle, he refers to the 'tendency for them (constituent agreements) to produce exceptions to the rule that a treaty cannot confer benefits or impose burdens upon third parties' ${ }^{200}$ More recently, Brownlie has accepted such a position, noting that an exception to the pacta tertiis rule

'rests on the special character of the United Nations as an organisation concerned primarily with the maintenance of peace and security in the world and including in its membership the great powers as well as the vast majority of states' ${ }^{201}$

Although it may be that Brownlie views the UN as a sui generis case by virtue of its special position, the reasoning used to explain the exception to the pacta tertiis rule strongly parallels the rationale for objective regimes.

Since the founding of the UN, the international law has expanded this category of 'fundamental norms' beyond the sphere of peace and security, and the existence of such legal norms is generally accepted, despite the conceptual difficulties they present or particular disputes over their individual status. $^{202}$ In this respect objective regimes, and the notion of general interests in particular, relate closely to the category of ius cogens, and may be affected by the same conceptual problems. The crux of the issue is the primitive process that creates and identifies such peremptory norms. In the absence of an international legislature, or institutional mechanism for creating such fundamental rules, the formulation of such rules appears to rely on a process of historical consolidation, which makes their existence difficult to ascertain, or at least open to equivocation. This is, of course, attributable to the bilateral structure or the international system that we have inherited. However, this should not be viewed as critical, for as the ILC has stated:

'It is not the form of a general rule of international law but the particular nature of the subject matter with which it deals that may ... give it the character of ius cogens. ${ }^{203}$

We can, therefore, look beyond these structural problems and to the substance of the rule in order to gauge its normativity. Thus, the problem is not whether a category of general interest justifies an exception to the pacta tertiis rule, but rather the quest to identify the interests that are included

\footnotetext{
199 International Law, 2nd. ed., vol. i, Peace, 30.

200 Op. cit., n. 4, at 750.

201 Brownlie, op. cit., n. 4, at 694.

202 Articles 53 and 64 of the Vienna Convention on the Law of Treaties. See generally, G. Danilenko, 'International Jus Cogens: Issues of Law Making', (1991) 2 EJIL 42.

203 Report of the International Law Commission, [1966] YILC vol. II, 248.
} 
within this category, and subsequently whether or not a particular objective regime furthers this general interest.

Undoubtedly, there exists a general interest in international peace and security as enshrined in the United Nations Charter and, more particularly, in the prohibition on the unlawful use of force. This has underpinned numerous demilitarisation and neutrality regimes, ${ }^{204}$ and served to legitimate the so-called Zones of Peace. Equally certain is the general interest in political stability, as embodied in those regimes regulating the status of territories such as the mandate territories or internationalised territories. ${ }^{205}$ The special character of boundary treaties reflects this interest, ${ }^{206}$ and certain fluvial rights have also been held to be in the general interest, hinting at a general interest in the form of a ius communicationis. Arguably, this same interest underpins rights of navigation, over-flight, transit and innocent passage, and which the Permanent Court recognised in the Wimbledon case when stating that:

'[The] canal has ceased to be an internal and national navigable waterway, the use of which by the vessels of States other than the riparian State is left entirely to the discretion of that State, and that it has become an international waterway intended to provide under treaty guarantee easier access to the Baltic for the benefit of all nations of the world'. ${ }^{207}$

As was seen in Part II, certain other general interests exist, but are less certain. With regard to the Antarctic, demilitarisation and peaceful use of the territory are generally accepted, but resource exploitation regimes have proved to be problematic. The common heritage of mankind regime for the Area is similarly affected by difficulties in agreeing a resources regime, although a moratorium on territorial claims has been successful. Similar problems may face us if outer space were to become commercially exploitable.

Arguably, a general interest may exist in respect of the protection of the environment, as manifest in principles such as the polluter pays principle, ${ }^{208}$

\footnotetext{
204 The Committee of Jurists reasoned that the Treaty of Paris 1856, which placed the Aaland Islands under a regime of permanent neutrality was laid down in European interests. They constituted a special international status, relating to military considerations, for the Aaland Islands. It follows that until these provisions are duly replaced by others, every State has the right to insist upon compliance with them. It also follows that any State in possession of the Islands must conform to the obligations binding upon it, arising out of the system of demilitarisation established by these provisions.' Op. cit., n. 161, at 18.

205 International Status of South West Africa Advisory Opinion, supra n. 39. Also the Certain Phosphate Lands in Nauru (Nauru v. Australia) (Preliminary Objection), ICJ Rep. 1992, 240, 251253.

206 See the Free Zones case and the Temple of Preah Vihear case, op. cit.

2071923 PCIJ Sser. A, No. 1, at 22.

${ }_{208}$ P. Birnie and A.E. Boyle, International Law and the Environment (1992), 109-111.
} 
the precautionary principle, ${ }^{209}$ the sic utere principle and prohibition on transboundary harm, ${ }^{210}$ and the notion of equal access and non-discrimination. ${ }^{211}$ The notion of trusteeship is rapidly gaining credence and might be perceived as another expression of the general interest. ${ }^{212}$ Indeed, the status of such principles was recently boosted by the decision of the ICJ in Gabč $i$ kovo-Nagymaros Project case where the Court, in the context of article 64 of the Vienna Convention 1969, pointed out:

'[T]hat newly developed norms of environmental law are relevant for the implementation of the Treaty and that the parties could, by agreement, incorporate them through the application of Articles 15, 19 and 20 of the Treaty. These articles do not contain specific obligations of performance but require the parties, in carrying out their obligations to ensure that the quality of water in the Danube is not impaired and that nature is protected, to take new environmental norms into consideration when agreeing upon the means to be specified in the Joint Contractual Plan'. ${ }^{213}$

The conservation and management of living resources of the seas is another such interest, as is evident in the context of the LOSC, the 1995 Agreement, and other fisheries instruments.

This brief review suggests that the validity of a particular objective regime bears a symbiotic relationship to the general interest it purports to serve. The greater the degree of acceptance of the general interest it serves, the more likely the acceptance of the objective regime. For example, the objective status of neutrality and demilitarisation agreements has attracted a stronger level of support from States given the universality and greater acceptance of the general interest in the restriction on the use of force as a tool of international relations. This may be contrasted with environmental regimes, which have developed more recently, and are not yet as deeply entrenched in the collective international psyche.

At the same time one must also consider whether the treaty actually facilitates the general interest in question. Whether or not this happens again turns on the particular circumstances of each case. A bald assertion that the treaty is in the general interests is insufficient in this respect. The existence of a general interest is independent of the assertions of the States parties and requires an analysis of the legal context of the objective regime. This operates as a safeguard against a group of States exercising an illegitimate legislative power, and prevents possibility of a group of States making a subjective

\footnotetext{
209 Ibid. $95-98$

210 Trail Smelter case, (1939) 33 AJIL 182, and (1941) 35 AJIL 684.

211 Op. cit., n. 208, at 111-112.

212 See Lowe, 'Some reflections on the Water. Changing Conceptions of Property Rights in the Law of the Sea', (1986) 1 IJECL 1. Also Allott, op. cit., n. 12.

${ }^{213}$ Op. cit., n. 17, para. 112. See R. Wolfrum, 'International Environmental Law' (1998) 272 RdC 9, 102.
} 
determination of what constitutes a general interest. The legitimacy of a particular regime might be evidenced by the decision of an international tribunal, or by acquiescence to it from third States, or by tacit acceptance. It is, however, important to note that the basis of any obligation flows from the norm articulated in the treaty, and not from the manifestation of consent. As the treaty regime articulates a general interest (ius cogens or ordre public) in a particular form, the opposability of which is considered not to rely on consent, it would be artificial to make the opposability of it in the specific form of an objective regime dependent on consent.

The unifying thread common to all examples of objective regimes is the notion of general interests. This common thread not only determines the validity of each regime, but provides legitimacy to the entire concept. As a normative process, objective regimes make a general interest opposable to third States in a specific form; they define the general interest in sufficient detail to make it opposable as a specific legal obligation. In other words, objective regimes derive their force by tapping in to the fundamental principles of international law and actualising them in a particular manner. Accordingly, any evaluation of an objective regime requires a thorough consideration of the general interest it claims to facilitate.

\section{CONCLUSION}

In the face of growing problems in prescribing for urgent matters of international public interest and common global concern, objective regimes offer an alternative approach to international law making. Ordinary treaties are ill-suited to deal with the problem of the free rider or the reluctant State, whereas custom is often difficult to evaluate, slow to emerge, and is inherently incapable of establishing precise standards of behaviour and institutional measures. With the emergence of the international law of human rights and international environmental law we are witnessing a paradigmatic shift in perceptions of the purpose of international law, and of the structure and make up of the system. Accordingly, the demands on the prescriptive process are changing, becoming more urgent and unsustainable. Objective regimes should be given greater attention, and not be rejected out of hand as anomalies, for they are well suited to addressing the concerns outlined.

Objective regimes are justified by a rejection of a linear and bilateral conception of international law and offer themselves up as a surrogate for a general legislative power absent from contemporary international society. However, the risks inherent in such a power require that objective regimes be sufficiently defined and regulated in order to avoid abuses that might result from a group of powerful States' attempting to legislate for the international community contrary to this group's interests. There is a substantial amount of State practice supporting the existence of a category of objective territorial arrangements, contrary to or as an exception to the pacta tertiis rule. Tradi- 
tionally, such arrangements have been confined to arrangements necessary to secure order after a period of political upheaval and instability, although more recently there is evidence of objective regimes being established to further environmental considerations or to establish nuclear-weapon-free zones, e.g., Antarctica or Zones of Peace. From an investigation of State practice and doctrine certain parameters to objective regimes were discerned. There must be an intention that the treaty have objective effect, the regime must be a territorial regime, the parties to the treaty must have a particular competence or interest in the regime, and there must be a general interest of the international community in the objectives of the regime.

Of these factors, two appear to be of fundamental importance: the existence of a general interest, and the particular competence of a group of States to accommodate the general interest within the particular instance. There is no hard and fast rule of thumb that sets out the minimum criteria for an objective regime, and each case must be assessed on its own merits. The validity of a regime will depend on a number of factors, including the quantity and quality of the contracting parties, the nature and scope of the rights and obligations established, the identity and quality of the general interest, and the reaction of other States to the regime. In addition, it must be remembered that the burden of establishing a regime is onerous. As the Permanent Court stated in the Free Zones case, 'it cannot be lightly presumed that stipulations favourable to a third State have been adopted with the object of creating an actual right in its favour. ${ }^{214}$ The burden thus lies on those seeking to establish that such rights and obligations exist. The ICJ reiterated this in the North Sea Continental Shelf cases:

'[W]hen a number of States ... have drawn up a convention specifically providing for a particular method by which the intention to become bound ... is to be manifested ... it is not lightly to be presumed that a State which has not carried out these formalities ... has nevertheless somehow become bound in another way'. ${ }^{215}$

Unfortunately, the legitimacy of an objective regime has not been tested directly by an international tribunal. As such, their status lies in limbo: in that grey space in between de lege ferenda and lex lata. Reference to the objective effects of treaties is likely to become an increasingly salient feature of doctrine, given the changing demands being placed on international law. As the need for new initiatives to tackle environmental and resource problems becomes more apparent, this can only be in our general interest.

Op. cit., n. 155.

215 ICJ Rep. 1969, 4 at 25-6. 